
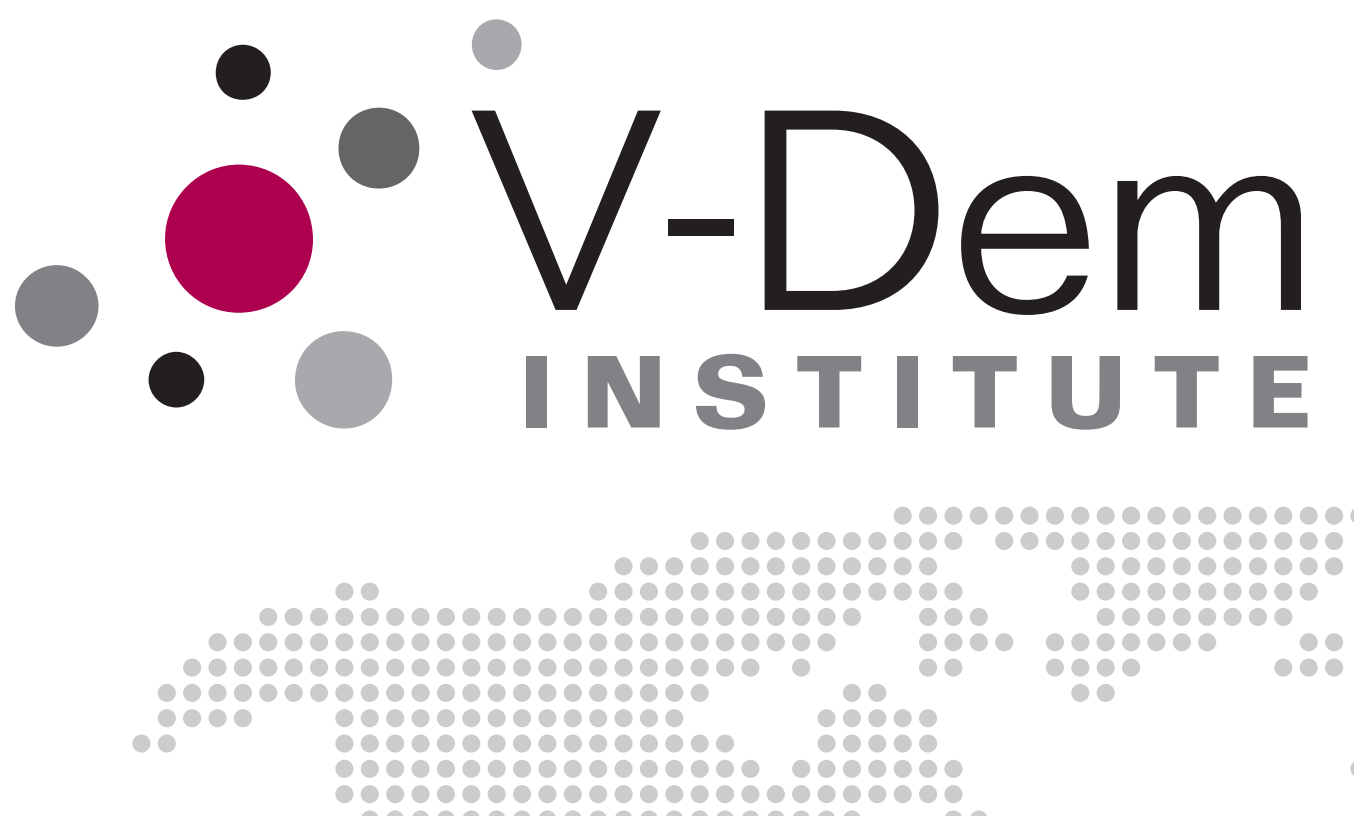

No Democratic Transition Without Women's Rights: A Global Sequence Analysis 1900-2012

Yi-ting Wang, Patrik Lindenfors, Aksel Sundström, Fredrik Jansson and Staffan I. Lindberg

00000000

0000000

000000

10000

10000

090

1000

10

10

89
00000

क्रि080

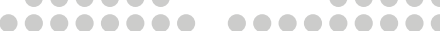

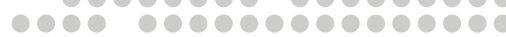
000000000000000000 00000000000000000 -

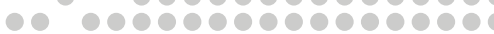

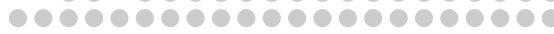
-

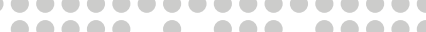

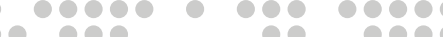

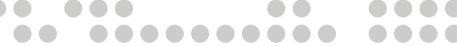

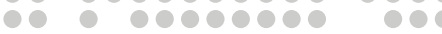

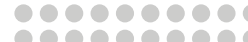
8

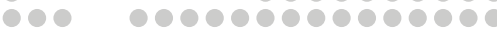

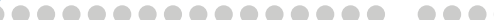

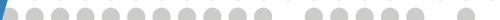

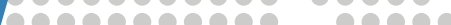

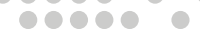

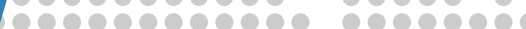

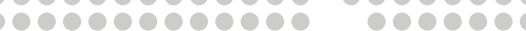
1000000000000000000

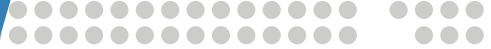
000000000000000

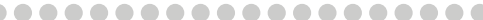

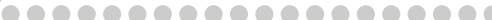
-

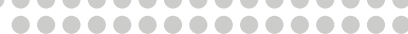
९0000000000000 6909090909090

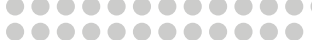
69698090800 6090900000 00000000000

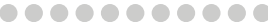
00000000000

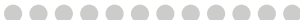
róróró 00000000 100000

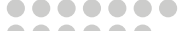

000000 0000 100 \section{:}

20

10 
Varieties of Democracy (V-Dem) is a new approach to the conceptualization and measurement of democracy. It is co-hosted by the University of Gothenburg and University of Notre Dame. With a V-Dem Institute at University of Gothenburg that comprises almost ten staff members, and a project team across the world with four Principal Investigators, fifteen Project Managers, 30+ Regional Managers, 170 Country Coordinators, Research Assistants, and 2,500 Country Experts, the V-Dem project is one of the largest-ever social science research-oriented data collection programs.

Please address comments and/or queries for information to:

V-Dem Institute

Department of Political Science

University of Gothenburg

Sprängkullsgatan 19, PO Box 711

SE 40530 Gothenburg

Sweden

E-mail: contact@v-dem.net

V-Dem Working Papers are available in electronic format at www.v-dem.net.

Copyright (C) 2015 by authors. All rights reserved. 


\title{
No Democratic Transition Without Women's Rights: A Global Sequence Analysis 1900-2012*
}

\author{
Yi-ting Wang \\ Assistant Professor \\ National Cheng Kung University \\ Patrik Lindenfors \\ Associate Professor \\ Stockholm University \\ Aksel Sundström \\ $\mathrm{PhD}$ Candidate \\ University of Gothenburg \\ Fredrik Jansson \\ Postdoctoral Researcher \\ Institute for Analytical Sociology \\ Linköping University \\ Staffan I. Lindberg \\ Professor of Political Science \\ Director, V-Dem Institute \\ University of Gothenburg
}

\footnotetext{
* This research project was supported by Riksbankens Jubileumsfond, Grant M13-0559:1, PI: Staffan I. Lindberg, V-Dem Institute, University of Gothenburg, Sweden; by Swedish Research Council, 2013.0166, PI: Staffan I. Lindberg, V-Dem Institute, University of Gothenburg, Sweden and Jan Teorell, Department of Political Science, Lund University, Sweden; by Knut and Alice Wallenberg Foundation to Wallenberg Academy Fellow Staffan I. Lindberg, V-Dem Institute, University of Gothenburg, Sweden; by University of Gothenburg, Grant E 2013/43.
} 


\begin{abstract}
What determines countries' successful transition to democracy? Research has focused on socioeconomic and institutional factors, yet the assumption that political liberalization has to precede democratization has not been systematically examined. We explore the impacts of granting civil rights in authoritarian regimes and especially the gendered aspect of this process. We argue that both men's and women's liberal rights are essential conditions for democratization to take place: giving both men and women rights reduce an inequality that affects half of the population, thus increasing the costs of repression for authoritarian rulers, and enabling the formation of women's movements - historically important as a spark of protests in initial phases of democratization. We test this argument empirically using data that cover 160 countries over the years 1900-2012 and contain more nuanced measures than commonly used. Through sequence analysis we obtain results suggesting that liberal rights for both men and women enhance civil society organizations, and then lead to electoral democracy. The results suggest that influential modernization writings - stressing the role of economic development in democratization processes - may partly have been misinformed in their blindness for gender. The reported pattern may be at least part of the explanation of the 'Arab spring' failures.
\end{abstract}


"The majority of the mainstream democratization literature has remained gender blind, with very little to say about the participation of women in transitions to democracy or the gendered nature of those processes" (Waylen 2003, p. 157)

\section{Introduction}

Is the improvement of women's civil rights a necessary condition for countries to democratize? There are some early studies discussing the evolution of citizen rights and their sequence. For instance, Marshall's (1950) seminal work suggested that legal rights come first and, followed by political and social rights, that participatory rights were the final stage of this sequence (see also Janosky 1998). The literature has also long been pointing out the distinction between political liberalization and democratization, and how the process of liberalization tends to precede a democratic transition (Linz and Stepan 1996, Przeworski 1991). Political liberalization includes the elimination or reduction of state repression and extension of civil liberties. It is believed that once authoritarian rulers ease their control over citizens, citizens have more opportunities to challenge existing political leaders and institutions. With liberal rights, citizens have a stronger standing in the public sphere and are better able to organize in political movements to demand democratic rights, and hence improving the overall participatory environment and increasing the cost of repression for authoritarian rulers.

However, as Davenport (2007) has pointed out, these insights have not been systematically examined; despite the conceptual importance of distinguishing between the two processes, they are seldom operationalized separately in the quantitative analysis. Does the entitlement of civil rights always precede the establishment of competitive elections for political leaders and thus constitute a precondition for democratization? One reason that this question has not yet been thoroughly investigated is that some scholars believe that the protection of liberal rights is an aspect of democracy (Beetham 1999). The two processes tend to be highly correlated and temporally close to each other, and therefore the relationship between them is difficult to explore.

Another deficiency in the literature is that when stressing the importance of civil rights, research has remained gender blind and has not addressed that the development of civil rights for women tends to lag behind the rights of men. It is not clear if it is necessary to achieve some degree of gender equality with regard to civil rights before democratization. However, the connections between the rights of women and democratic outcomes have been discussed in early works. For instance, Tocqueville (1835) argued that the expanded educational opportunity 
for women goes along with a society more receptive to democracy. Mill (1869) proposed that without the right to vote, women would in fact not develop the skills of active citizens.

Case study evidence suggests that women have been among the first to speak up against authoritarian rule in Latin American countries such as Argentina, Chile and Brazil (Waylen 1994), in Sub-Saharan African countries (Tripp 2001) as well as in some countries in the Middle East and North Africa (Arat 1994, Moghadam 2008). Women's organizations, often being outsiders of conventional politics, have in numerous settings been operating under the radar of authoritarian regimes oppressing established opposition parties and extending the space allotted for civil society organizations, thus creating a foundation for protests in the initial phases of transition (Arat 1994, Waylen 2007). Based on samples that mostly span across the past twentyfive years, quantitative studies also identified that more equal distribution of education between women and men (Barro 1999, Fish 2002, Sanborn and Thyne 2013), female labor force participation (Wyndow et al. 2013), and the conception of gender equality as a part of broader cultural changes (Inglehart et al. 2002), are factors that contribute to democratization.

There are two literatures on democratization that bolster our expectations about these connections. On the one hand, a macro-level literature that focuses on structural factors lends us to reason that the "costs of repression" is increased as half of the population increasingly gain the rights to move, discuss and hold material and immaterial assets. On the other hand, a literature with a micro-level focus informs our argument that such rights have in fact been crucial for enabling the organization of women's movements that in a range of countries have initiated protests that led to transitions. By exploring the effects of empowerment of men and women separately, and examining the consequences on regime changes when women's rights lag behind, our argument departs from the current transition literature. More specifically, we hypothesize that if women are denied basic liberties and rights, then they will have a lower standing on the labor market and in the public sphere. Once women enter the workforce, they have an increasing demand for redistribution and public goods provision, such as low-cost daycare, which are linked to a political regime more responsive to the needs of its people. In addition, only when women have basic liberties and rights are they able to develop the skills required to organize movements that oppose authoritarian rule. Parallel to the argument holding that economic inequality is a determinant for democratization (cf. Lipset 1959, Acemoglu and Robinson 2006), we believe that this inequality in civil liberties and rights between men and women - such as whether or not women are free to move, discuss and to hold material and immaterial assets will affect women's demands for redistribution and their organizational capacity, and thus the costs of repression. 
We identify three lacunas in the scope of the current research: first, the often-mentioned assumption that political liberalization has to precede democratization has not been systematically examined. Second, there is a literature on democratization that seldom has focused on whether or not the rights of women are an important prerequisite for successful transition to take place. Third, there is a literature on gender and politics that has focused on democratization, yet mostly on the impact of such processes on gendered outcomes, such as women's political representation and the effectiveness of women's movements (Paxton et al. 2006, Viterna and Fallon 2008, Paxton et al. 2010, Viterna et al. 2010, Fallon et al. 2012), but that has not explored women's rights as a determinant for successful democratization. Moreover, the current state of research has some limitations in methods. One the one hand, the few qualitative case studies that analyze women's organizations in liberation processes focus on single countries and over a limited period of time. On the other hand, the existing quantitative studies that examine the relationship between gendered indicators and outcomes in democratization only study the most recent decades and use regression frameworks whereby it is difficult to identify the temporal relationship between variables and deal with endogeneity issues.

Our approach aims to remedy some of these problems. We utilize a newly collected dataset on both men's and women's rights, and measures of countries' transitions to democracy that, covering more than 160 countries for the years 1900 to 2012, are more detailed than commonly used. Moreover, we use a novel sequencing method that focuses on investigating the temporal process of events. In doing so, we are able to more systematically theorize and examine the relationships between liberal rights in various dimensions and democratic transitions.

The results from this analysis suggest that to gain electoral democracy a country first needs to give liberal rights to both women and men. We demonstrate that the improvement of civil rights is indeed a necessary condition for democratic transition to take place. In addition, we point out the importance of women's rights, and show that civil rights of both genders are crucial: only when both men and women have enjoyed certain levels of civil liberties, leading to increased civic skills in the population and a strengthening of civil society organizations, are regime changes more likely to occur.

These findings challenge influential thinking stemming from modernization theory, which holds that "dictatorships die as countries ruled by them become economically developed" (Przeworski and Limongi 1997, p. 156). In contesting this perspective, we agree with Waylen in stating that "any analysis of democratization that fails to incorporate a gendered perspective that ignores the actions and impact of certain groups - will be flawed" (1994, p. 327). Economic development leads to democratization only if the process brings about the enhancement of both 
men's and women's civil liberties. We thus propose that future research on democratization and regime transitions would benefit from increasingly taking gendered aspects into account.

The paper proceeds as follows: in the following section, we discuss theories linking civil liberties and democratic transitions, with a focus on the importance of women's rights. Next, we describe the sequence analysis approach, and specify data and measures utilized in this paper. We then present the empirical results. We conclude by outlining the implications of these findings and discuss the limitations and future extensions of the study.

\section{Women's Rights and Democratization}

In explicating our theoretical expectations we build on two types of reasoning in the scholarship on democratization, one focused on 1) changes in class power and demands for redistribution, and another on 2) mass behavior and participatory civil society.

\subsection{A Macro-Level Approach: Liberal Rights and the Cost of Repression}

Influential democratization scholars have discussed the role of economic development, the middle class, and economic distribution in transitions. Lipset (1959) states that there are social prerequisites for the rise and persistence of democracy, such as the affluence and prosperity of a country. Accordingly, economic development tends to reduce income inequalities and create a large middle class who may act as a political force to induce democratic reforms. We use theories on how income inequality affects democratization to craft a gendered version of this structural reasoning.

The literature focusing on the relationship between economic inequality and democratization identifies that resource redistribution from the rich/rulers to the poor/ruled is the natural consequence of regime transitions. Thus, the challenge to the authoritarian power structure comes from the lower classes, who wish to change the redistributional equilibrium in the society through democratization (Acemoglu and Robinson 2001, Boix 2003). Therefore, the possibility of a democratic transition is conditional on the relative costs of repressing the organized opposition of lower classes compared to the potential costs of redistribution under a future democracy, from rulers' point of view. At high levels of economic inequality, "the cost of redistribution surpasses that of repressing revolts. The elites hence repress the population and there is no democratization" (Houle 2009, p. 592). However, as the distribution of assets and income becomes more equal among individuals, the redistributive impact of democracy 
decreases, and repressing oppositions by force becomes less attractive (Boix 2003, Chacón 2012). As a democratic tax structure preferred by the median voter becomes less expensive to the rich, the probability of a transition to universal suffrage increases. The costs of repression relative to redistribution are not only determined by the levels of inequality, but also affected by sources of income of the elites (Moore 1966, Acemoglu and Robinson 2006). When capital owners tend to rely on labor repressive institutions rather than cooperative mechanisms in the workplace to generate revenues, having a democratic system is especially expensive to them.

While this reasoning refers to the general economic equality in a country, one may see this thinking very well be applicable to a gendered understanding of such processes, that is, why the strength (or absence) of civil liberties for women may be important for such transitions to take place. First, let us remember that democracies are more prone to grant women - one half of the population - a larger share of the resources and power than autocracies, since the preference of the median voter is likely to shift policy toward a more woman-friendly standpoint. Second, we should recall that most authoritarian regimes are ruled by men. They have - parallel to the argument on income equality between the rich and the poor in society - also much to lose if women may ask for their share of the cake. We therefore believe that countries where women are denied their basic rights - highly gender unequal countries - are less likely to democratize since the cost of redistribution surpasses that of repressing revolts (cf. Houle 2009) and the elite will have much to lose in letting democratic elections decide their future.

In addition to reducing the general inequality in a country, the improvement of civil liberties for women also raises the demands for wealth redistribution and a democratic tax structure through two avenues. First, as Iversen and Rosenbluth (2006) point out, women's policy interests change as they enter the workforce. Since women are more likely to be the primary care givers, working mothers' welfare is largely affected by the availability of some public infrastructure, such as low-cost child day care. As studies find, at any given level of income, working women prefer more social protection than both men and housewives (Greenberg 2000, Iversen and Rosenbluth 2006). The demands for social welfare policies are linked to a political regime more responsive to its citizens' needs. That is, once more women obtain basic liberties, such as property rights and the freedom of movement, and enter the workforce, the general preferences for social policies increase, which are more likely to be achieved in a democratic tax structure.

The second avenue is that the advances in women's civil rights, which are helpful in the improvement of their economic participation, produce many additional socio-economic gains and can lead to a growing middle class. A strong middle class has long been considered as a key 
factor in explaining democratization, either as the driver of the transition process or as a buffer in the conflict between the elite and the citizens (Acemoglu and Robinson 2006). Studies point out that women are more likely than men to save and reinvest their earnings to their household, and thus the increased gender equality in rights and resources helps reduce household poverty and improve the well-being of their next generation (Frey and Field 2000, Jowett 2000, Morrison et al. 2007). That is, since women tend to contribute more to family income than men, the improvement of women's rights is expected to more effectively change the class structure by reducing household poverty and enlarging the middle class.

Based on these arguments, we propose that the absence of civil liberties and rights for women can be viewed as another type of inequality that affects the "costs of repression". In addition, the improvement of women's rights increases the costs of repression not only by reducing the general inequality in a country, but also by increasing the demand for redistribution and enlarging the middle class through women's labor participation and earnings.

\subsection{A Micro-Level Approach: Women's Abilities to Organize Themselves in Movements}

The other reasoning is focused on mass behavior and draws on scholarship on gender and politics that has discussed how women's labor market involvement produces civic skills that affects their capacity for political participation as well as how women's organization in movements for democratic reform may be crucial during transitions. As stated by Weingast (1997), for scholars of democratization "mass behavior is relevant because citizens must coordinate their reactions to prevent violations of democratic rights" (p. 246).

A fundamental change occurring in a society in which women receive rights, such as freedom from slavery and the right to hold property, is that it will witness an increasing share of women on the formal labor market. There is ample research on the effects of increasing participation of women in the formal labor market. Iversen and Rosenbluth (2008) discuss early liberal's resentment of British coverture laws, that is, where fathers or husbands controlled the labor of dependents and wives:

"As long as women are not allowed to own their labor, they argued, women lack the motivation or capacity to be morally responsible. Without resources of their own, females connive to get what they want from males, and being disenfranchised they have no incentive to become informed and constructive citizens" (p. 8). 
In this line of reasoning, it is conceivable that an active engagement in the labor market may foster skills crucial for political participation and democracy movements. As Matland (1998) states, this process "has a consciousness raising effect on women's political participation and their propensity to articulate political demands" (p. 118). Research from both developed and developing countries suggests that women who are established in the labor market and form an identity from such experiences, are more likely to be interested in and participate in conventional politics (e.g. Welch 1977; Schlozman et al. 1999; Chhibber 2002). Ross (2008) summarizes these findings: "When women enter the workforce they become more likely to engage in conversations that promote an interest in politics, to join informal networks that facilitate collective action and help them develop their civic skills" (p, 108). Moreover, there may be a "spill-over" effect from gaining such skills: "Women, who enter the labor force, may also become part of greater organizational networks such as trade unions and business groups; groups where they are very likely exposed to politics" (Stockemer and Byrne 2013, p. 4).

Along with this process on the labor market that generates the civic skills necessary for participation, the granting of rights - specifically the freedom of domestic movement, the freedom of discussion, and access to justice and power - will tend to spur women to organize in civil society associations. This is a feature we believe to be crucial. In fact, research from a range of countries suggests that women's organizations played key roles during initial phases of opposition to authoritarian regimes.

This literature gives anecdotal insights in where such movements have mattered. Focusing on Latin America, Waylen (1994) notes that groups in the 1970s in authoritarian Chile and Argentina campaigned against human rights violations. One example is the Argentine las Madres de Plaza de Mayo (Mothers of the Plaza de Mayo) that would rally on a certain city square, carrying pictures of their disappeared children. In the 1980s groups emerged in Brazil, Chile and Peru that trough popular movements focused on the "politics of daily life" that struck women harder economically than men. For instance, in the urban protests during the 1980's against repression in authoritarian Brazil, $80 \%$ of the people are believed to have been women (Waylen 2007, p. 57). Waylen also notes women's groups appearing under authoritarian rule in Latin America that made strategic gender-based demands, and whose participants were often active in left-wing politics before military rule.

Writings on protest movements in the Middle East and North Africa suggest that women's organizations have played important roles in countries such as Turkey and Iran (Arat 1994; Moghadam 2004, 2010). It is said that “[i]n Morocco, women's groups were central actors in the country's democratization during the 1990s" (Moghadam 2008, p. 11). 
With regard to sub-Saharan Africa, women's organizations have played important roles in the move toward electoral democracy. In South Africa, women's organization had a tremendous impact in the struggle against apartheid (Waylen 2007). Moreover, Tripp (2001) gives numerous examples of African countries where democratization processes were sparked by protests organized by women:

"In Kenya, the early 1990s saw women at the forefront of often violent protests in support of imprisoned human rights activists. In Mali, thousands of demonstrating women and children were fired on by the forces of President Moussa Traoré in a series of events that led to his downfall. In Sierra Leone ... women were the only group that openly defied soldiers and demonstrated for a free vote. In Guinea, women organized a sit-in in front of the presidential palace in Conakry... Finally, in Niger, several thousand women demonstrated against the exclusion of women representatives from a preparatory commission charged with organizing the country's National Conference in 1991” (p. 142-143).

This vein of research also illustrates how and when these movements mattered. Importantly, studies suggest that women's organization throughout history have filled an organizational void in authoritarian systems that were originally perhaps less threatened by these groups. Arat describes how women in Turkey during the 1980s did this through "extending the space allotted to civil society organizations" (Arat 1994). Similarly, in Latin America authoritarian systems allowed women's organizations "space to mobilize" (Waylen 1994, p. 339) and in absence of conventional politics allowed these groups influence through new modes of participation.

Research suggests that these organizations may function as a first spark for protests toward democratic change. Waylen (1994) argues that the impact of women's movements is important in initial phases of transition, before conventional forms of politics take form. As outsiders to orthodox politics, women's groups “formed the first organized and open opposition to authoritarian governments, helping to bring about the 'end of fear"' (p. 339). In Chile, for instance, one of the first mass protests against the Pinochet regime was supposedly held to celebrate the International Women's Day in 1978. Similarly, Tripp notes that women's groups in African countries undergoing transitions "were among the first to take advantage of new openings to establish a wide array of formal and informal associations at both the local and national levels" (2001, p. 147). 
Besides the direct organization of women's movements, there are also other important effects to consider. Sanborn and Thyne (2013) notes that "even when females do not lead movements, the breaking of traditional norms of gender inequality empowers male leaders of democratization movements to lead more effective movements, recognizing that females can play a crucial role in agitating for political change" (p. 779). In such situations, they argue, that the rights given to women may strengthen political opposition as a whole: "When male leaders of political liberalization movements in Guatemala came to appreciate the power of female movements in the region, for example, they supplemented their ranks and extended leadership positions to females" (Sanborn and Thyne 2014, p. 779).

What these studies on women's role in protest movements suggest is that women's presence in the public sphere was crucial for successful transitions. Importantly, the absence of civil rights and liberties for women should therefore have the opposite consequence, where a large share of the population will remain in the private sphere, reluctant to engage in political activities. As Jaquette (2001, p. 116) points out: "[Such states] are also patriarchal, hindering women's access to capital, land, and credit. Because women are marginalized from formal politics and their issues are 'depoliticized' they prefer to manage their affairs autonomously instead of engaging in public protests and organization." This reasoning suggests that states that deny women basic rights will tend to face less pressure from demands of political change.

In tandem, our macro-level and micro-level discussions outline that we expect civil liberties to be a condition for successful transitions to democracy. By granting civil rights to a larger share of population, citizens are better able to organize politically and challenge the regime, and the costs of repression increase, which consequently strengthen the possibility of democratic transitions. Within this framework, we focus on the importance of women's rights, and point out several mechanisms linking female liberties and regime changes. In countries where women have civil liberties and rights, the costs of repression for authoritarian rulers tend to be larger than in countries where half of the population is not granted such rights. Since women in settings without rights often lack experience of engagement in public life, such as working formally or engaging in political movements, they tend to stay in the domestic sphere and are less aware of the prospects of wealth redistribution. Moreover, these countries are less likely to have protest movements, and when they do, they are more easily oppressed by elites, since a smaller share of the population will engage in these. Therefore, the successful transition to democracy is expected to be more common after women have obtained civil liberties and rights. 
To summarize our reasoning, Figure 1 outlines the different stages of the macro- and micro-level processes in which women's rights condition successful transitions. It has to be noted that, in this paper, we mainly investigate the extent to which male and female civil liberties constitute a necessary condition for democratic transitions, and whether women's participation in civil society organizations is a mechanism linking improvement in liberal rights and the establishment of electoral democracy. Within this framework, other difference mechanisms will be examined in further work.

Figure 1: How women's rights condition successful transitions to democratic rule

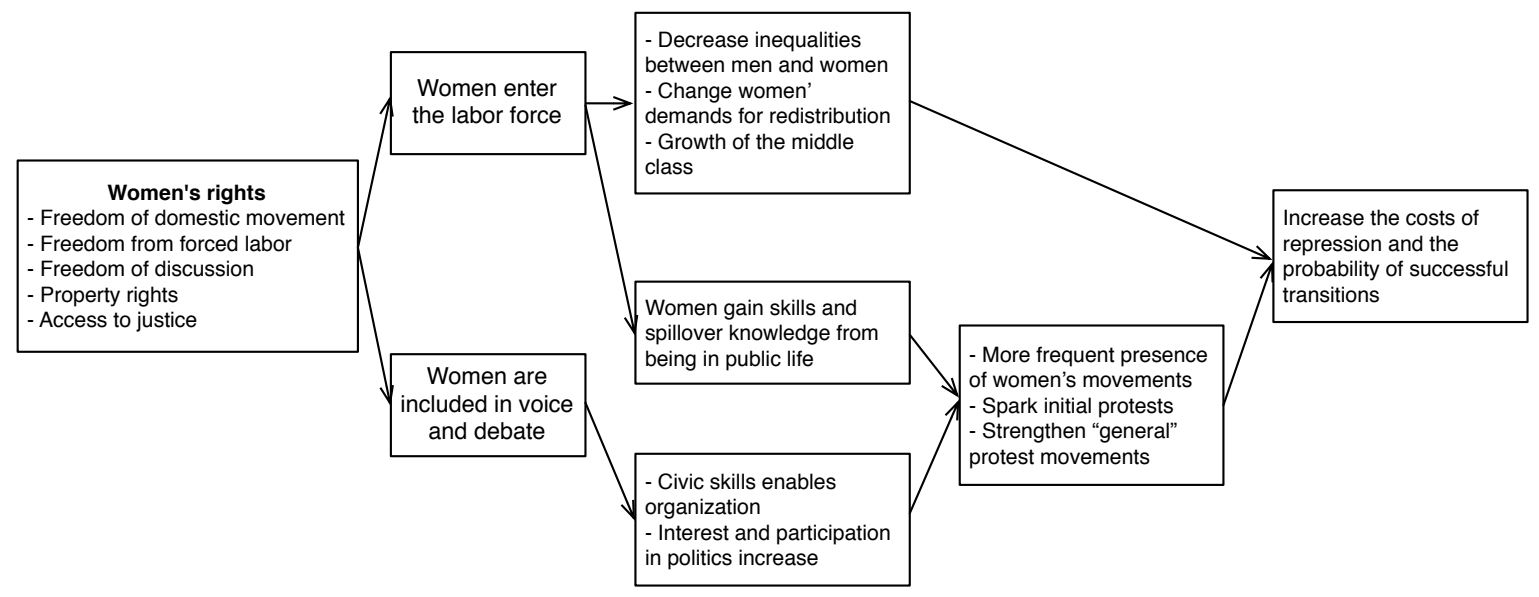

\section{Methods}

More or less inspired by comparable analyses in biology, scholars have developed several approaches to identifying sequences in time-series data in the social sciences. For example, inspired by studies on DNA sequence analyses, social sequence analyses identify the similarity of sequences, and have been proposed to explore the temporal order of discrete events analyzed by social scientists, such as life course trajectories, job careers, decision-making, and crisis (Abbott 1995, Abbot and Tsay 2000, Casper and Wilson 2015, Gauthier et al. 2010). However, the phenomena we are interested in here, the relationship between levels of female empowerment and successful democratic transitions in different countries and years, involve more than one variable measured mainly on an ordinal scale. To explore combinations of changes in these various variables over time, we have implemented several approaches, including fixed-effect regression with one year lag in the dependent variable, frequency and dependency analyses, a modified version of Qualitative Comparative Analysis (QCA) (Ragin 1987, Rihoux and Ragin 
2009), as well as a Bayesian dynamical systems approach (Spaiser et al. 2014; Ranganathan et al. 2014a). We will also use a novel graphical approach to investigate relationships between changes in two ordinal variables.

\subsection{Frequency Analysis}

To explore the temporal relationship between two variables we investigate whether one of them in general tends to be larger than the other. We therefore construct a frequency table including all possible combinations of the values of these two variables. An example of such a frequency table for two sample variables, Variable A and Variable B, is shown in Table 1. To calculate the frequency of each combination, for each country, we first combine several yearly observations when the values of both variables do not change into one observation and count them as one "event", regardless of how many years that combination is stable. Then we count the occurrences of each combination.

Table 1: Example of a frequency table of observed combinations of values of two variables

\begin{tabular}{|c|c|c|c|c|c|}
\hline & & & ble & & \\
\hline & & 0 & 1 & 2 & 3 \\
\hline & 0 & 4 & 3 & 1 & 0 \\
\hline & 1 & 1 & 3 & 5 & 1 \\
\hline Variable B & 2 & 0 & 0 & 3 & 4 \\
\hline & 3 & 0 & 0 & 0 & 3 \\
\hline
\end{tabular}

\subsection{Graphical Investigation of Changes}

Frequency analyses allow us to explore how often one variable is larger than another, but do not really clarify how this comes to be. To further investigate the exact pathways for how variables change, we have used a graphical approach. The rationale for this approach is elaborated upon in Appendix A.

To create the plots indicating temporal changes in two variables, we first construct a table listing all the observed changes in values of the two variables, then produce a figure mapping all these changes (see the Results section). We report two types of figures. In the first, we map all changes using arrows indicating movement between states, where the thickness of each arrow is proportional to the number of changes that have occurred along that particular path. We have also added circles in the graphs to indicate the number of times that particular 
combination of states is the end result of a change - the size of each circle is proportional to the number of "landings" on that particular combination. These are comparable to the numbers reported in the frequency tables, except that the initial state for each country is not included in the figures ${ }^{1}$. We arbitrarily chose "landings" over all observations to better give an indication of the direction of change.

The other type of figure reveals reform paths that are more popular than expected by utilizing observed data of the end result of changes (indicated by the circles in the first type of figures) to calculate a table of expected values using chi-square methodology from the distribution of each variable. Graphing the difference between the table of observed and the table of expected values reveals reform paths that are more popular than would be expected by the distribution of the two variables alone (see the Results section).

If one wants to draw conclusions about sequences from these graphs, the proposed approach assumes that variables change along a similar scale, with a similar step size, with each categorical score indicating a similar magnitude, and that no parts of the transition processes are systematically underestimated. It may be tempting to use observed and expected tables discussed in the previous paragraph to also calculate the chi-square statistic, but since the two tables may differ for reasons other than there existing popular reform paths, a significance value is not meaningful - hence the visual inspection is of crucial importance. If significance tests are deemed desirable (we urge caution as this requires that many assumptions are fulfilled), we instead recommend quasi-symmetric model tests for comparing off-diagonal values in square tables (Agresti 2002) utilized on the observed frequencies.

\subsection{Dependency Analysis}

To explore whether certain values of one variable are systematically conditional on certain values of other variables in the existing data, we have adopted something akin to a bare-bones version of QCA, here termed dependency analysis. The method is inspired by "the contingent states test," which was an early method developed to investigate dependencies in biological evolution (Sillén-Tullberg 1993), and is particularly well suited to use on sequence data outside biology. To conduct this type of dependency analyses, for each value of one variable, we scan the dataset for the lowest value in the others. If higher values in Variable A always correspond to higher "lowest values" in Variable B, then it can be inferred that certain values of Variable A are likely to be

\footnotetext{
${ }^{1}$ Note that in our examples, changes going up and going down are mapped simultaneously as there are no important differences between the paths in the two directions in our data, regarding which side of the diagonal changes tend to occur, though theoretically these may differ substantially.
} 
conditional on certain values of Variable B. If, simultaneously, for each value of Variable B, the corresponding "lowest value" in Variable A is its minimum, then this shows that Variable B is not restricted by Variable A. These two observations in combination indicate that potential dependencies between the two variables exist only in one direction. Dependency should not be taken here as a causal relation between $\mathrm{A}$ and $\mathrm{B}$, but only that certain values for a variable are conditional on certain values for the other variable in the available observations.

Note that even though Variable A and Variable B may covary, this method checks for absolute dependencies in the data, not statistical correlations. To allow some margin of errors, a percentile of observations can be specified and treated as the "lowest values," which will slightly relax the criterion of absolute dependencies. We here report both absolute dependencies and dependencies allowing a 95\% "wiggle-room," as is sometimes implemented in QCA.

Table 2 shows an example of such a procedure. The left table (a) indicates that higher states (2 and 3) in Variable A occur only together with higher values in Variable B (2 and 3, respectively). The right table (b) indicates no such dependency, with the exception that Variable $\mathrm{B}$ is never 3 if Variable A is not at least 1. Thus, variable A is likely dependent on changes of Variable B having taken place at several stages, while in the opposite direction there is a dependency only in that $\mathrm{B}$ cannot obtain the maximum value while $\mathrm{A}$ is at its minimum.

Table 2: Examples of dependency tables

(a)

\begin{tabular}{ll} 
Variable A & $\begin{array}{l}\text { Lowest value of } \\
\text { Variable B }\end{array}$ \\
\hline 0 & 0 \\
1 & 0 \\
2 & 2 \\
3 & 3
\end{tabular}

(b)

\begin{tabular}{ll} 
Variable B & $\begin{array}{l}\text { Lowest value of } \\
\text { Variable A }\end{array}$ \\
\hline 0 & 0 \\
1 & 0 \\
2 & 0 \\
3 & 1
\end{tabular}

\subsection{Bayesian Dynamical Systems Analysis}

Democratic development can sometimes be abrupt and clearly nonlinear, suggesting threshold values that change the speed or direction of development (Lindenfors et al. 2011; Jansson et al. 2013; Spaiser et al. 2014). In order to study nonlinear dynamics in the interaction between variables, and to potentially identify threshold values for the development of democracy and civil liberties, we also employ a newly developed Bayesian dynamical systems approach that models the probable reform direction of countries depending on state combinations. This method 
identifies the best nonlinear functions that capture the interactions between variables. Bayes factors are employed to decide how many interaction terms should be included in the model, with a punishment for overly complex models. The method gives a pair of differential equations, modeling how the values in each of the two variables involved affect the direction of each. From this, we can infer which is the most likely trajectory a country will follow, given any starting point. The resulting dynamical system can be illustrated by a phase portrait, where the trajectories are depicted with arrows. The method is described in full in two papers by Spaiser et al. (2014) and Ranganathan et al. (2014b). ${ }^{2}$

It is important to note that the method provides a system for the entire set of possible values for the two variables. That is, it uses all the data points and provides a general description for the entire system, including combinations of the two variables that do not occur in the data. For illustrative purposes, we do not plot the arrows for these points in the phase portraits.

\section{Data and Measures}

To explore the temporal relationship between the improvement of civil rights for both genders and democratic transitions, we utilize the data collected by the Varieties of Democracy (V-Dem) project. This is a new dataset that collects data on more than 300 indicators measuring different dimensions of democracy in 173 countries around the world from 1900 to 2012. Different from exiting datasets, which usually relied on a small group of experts who rated all countries or asked each expert to code one single unit, the V-Dem project invited over 2,500 local and crossnational experts to provide judgments on various indicators about democracy (Coppedge et al. 2011, 2014). Experts' ratings are aggregated through a Bayesian item response theory model (Pemstein et al. 2014). The model takes into account the possibilities that experts may make mistakes and have different scales in mind when providing judgments. In addition, bridgingcoders, experts who coded multiple countries, were recruited to calibrate the scales of estimates cross-nationally.

We define democratic transition as "any significant move toward mass democracy" (cf. Acemoglu and Robinson 2001, p. 938). We follow a focus in the literature on free and fair elections as well as multiparty competition as the core element of democracy (see Diamond 2015, p. 141). To measure the existence of free and fair elections, we utilize the electoral component index developed by Jan Teorell and included in the V-Dem dataset (Coppedge et al.

\footnotetext{
${ }^{2}$ We have used the R package bdynsys (Ranganathan et al. 2014b) to carry out the computations. The program presents the models that best fit the data using up to six terms. Unless otherwise mentioned, we have used the differential equations with the largest Bayes factors among these.
} 
2014). The electoral component index intends to measure the extent to which the electoral principle of democracy is achieved in the country. That is, whether political leaders in a country are selected through the mechanisms of competitive elections, and thus have to be accountable to their citizens at least to some extent. The index combines indicators on the level of suffrage, freedom to join political and civil society organizations, whether elections are clean and without systematic irregularities, and whether the chief executive is selected through elections.

The V-Dem dataset includes several measures on levels of civil liberties. We utilize the indicators with regard to five features: freedom of domestic movement, freedom from forced labor, freedom of discussion, property rights, and access to justice. All these indicators are measured on the scale of 0 to 4 , where 0 represents no freedom at all, and 4 means full freedom. These five indicators are measured for men and women separately. They capture the extent to which citizens in a country are able to move freely, to discuss, and to have a basic share of property. If they are denied the rights, it is difficult for them to organize collectively and engage in political movement against authoritarian rule.

For these indicators, the measurement model produces interval-level estimates of latent traits roughly in a normal distribution, with 0 as the average and 1 as the standard deviation. For the sequence analyses, which require ordinal variables, we take the corresponding normal cumulative probability of each value and divide them into five ordinal categories based on the probabilities for all these variables ${ }^{3}$. The highest categories on the indicators of electoral component index indicate that in the country, suffrage is extensive, elections are clean, the chief executive is selected (directly or indirectly) through elections, and political parties operate freely. That is, the highest category on the aggregate electoral index can be defined as a successful transition to electoral democracy, and any increase on the index can be viewed as improvement in democracy.

The measure of a mechanism, women's participation in civil society organizations (CSOs), linking liberal rights and electoral democracy is also from the V-Dem dataset. The indicator captures whether women are prevented from participating in civil society organizations, and high values indicate no such incidence.

\footnotetext{
${ }^{3}$ For the sequence analysis, the pairwise variables are comparable in the sense that they both refer to probabilities associated with the values. The (normalized) probabilities of the continuous versions are still used in the Bayesian dynamical systems approach.
} 


\section{Empirical Results}

\subsection{Frequency and Dependency Analysis}

To examine the temporal relationship between civil liberties and the development of the electoral principle of democracy, we first compared male and female civil rights. To calculate the frequency of each combination, for each country, we first combined several yearly observations when the values of both variables did not change into one observation and counted them as one "event", regardless of how many years that combination was stable. Then we counted the occurrences of each combination. We created frequency tables listing all the observed combinations between male and female civil liberty indicators, and then, as described in the methods section, calculated the percentage of observations where males had higher levels of civil liberties than females, in comparison to the opposite cases. Table 3 includes these percentages.

The relative percentages in Table 3 show that in the majority of cases, men have civil rights that are higher than or equal to those of women. Given the large disparity with respect to men's rights having larger values than women's rights versus the opposite, it is likely that male civil liberties tend to change before female civil liberties, especially when it comes to property rights and freedom of domestic movement, but less so for access to justice and freedom from forced labor, while the freedom of discussion mostly develops simultaneously for men and women. Note, by comparisons with frequency tables in Appendix D, that the frequencies are similar when civil rights are getting better as when they are getting worse.

Table 3: Relative frequencies of male and female civil liberties

\begin{tabular}{llll}
$A=$ Males, $B=$ Females & $\%$ when $A>B$ & $\%$ when $A=B$ & $\%$ when $A<B$ \\
\hline Property rights & 48 & 44 & 8.6 \\
Freedom of domestic movement & 37 & 55 & 8.1 \\
Access to justice & 27 & 62 & 11 \\
Freedom from forced labor & 26 & 60 & 14 \\
Freedom of discussion & 19 & 59 & 22
\end{tabular}

Then we compared the levels of both male and female civil liberties with scores of the electoral component index. Table 4 lists the percentages of observations where the values of the civil liberty indicators are greater than the values of the electoral component index, in comparison to observations where the values of the electoral index are greater. Note, by comparisons with frequency tables in Appendix D, that the frequencies are similar when civil rights and the electoral component index are moving up as when they are moving down 
Table 4: Relative frequency table of civil liberties and the electoral principle of democracy

Variable $A=$ Electoral
component index $\begin{gathered}\% \text { when } B>A \text { when } B= \\ A\end{gathered}$

Variable $B$

Property rights for men 92

Freedom of domestic movement for men $\quad 90$

Freedom of domestic movement for women 85

Property rights for women $\quad 80$

Freedom from forced labor for men $\quad 79$

Freedom from forced labor for women $\quad 74$

Freedom of discussion for men $\quad 60$

Freedom of discussion for women $\quad 59$

Access to justice for men

Access to justice for women

$\begin{array}{lll}92 & 8.5 & 0.1 \\ 90 & 8.3 & 1.4 \\ 85 & 13 & 1.8 \\ 80 & 16 & 3.7 \\ 79 & 18 & 3.3 \\ 74 & 20 & 5.2 \\ 60 & 32 & 8.6 \\ 59 & 31 & 9.6 \\ 55 & 32 & 13 \\ 49 & 35 & 16\end{array}$

The relative frequencies included in Table 4 shows that the electoral component index generally has lower values than property rights for men and women, freedom of domestic movement for men and women, and freedom from forced labor for men and women, but also, to a lesser degree, freedom of discussion for men and women and access to justice for men and women. Given the large disparity between the values for civil rights and the electoral component index, it is likely that a country's civil rights tend to attain high values before its performance on the electoral index achieves an equivalent level (assuming similar scales on all variables). Note that our results are not simply the consequence of differences in variable distributions, as the plots of observed versus expected indicates clear reform paths where civil rights score higher values than the electoral component index (see below, Fig. 4). It is likely that the development of both male and female civil rights is a precondition for having competitive elections. We have also constructed frequency tables for different subsamples, and found that the same pattern prevails for the early democracies, the third wave democracies, and when the post-communist countries are excluded (see Appendix B).

To investigate if having competitive elections depends on the development of both male and female civil rights, we conduct dependency analyses. Table 5 documents, across all observed combinations, countries' minimal scores for the civil rights indicators when the country scores $0,1,2,3$, or 4 on the electoral index. Numbers within parentheses are the absolute minimal values, while numbers outside parentheses are the fifth percentiles, which allow $5 \%$ margins of error. For example, there is no country scoring 2 on the electoral index when its level of property rights for men is not at least 4 , or 2 if one allows for a $5 \%$ wiggle-room. 
Table 5: Dependency table of the electoral component index on civil liberties

\begin{tabular}{l|lllll} 
Electoral component index & $\mathbf{0}$ & $\mathbf{1}$ & $\mathbf{2}$ & $\mathbf{3}$ & $\mathbf{4}$ \\
\hline Property rights for men & 1 & 1 & $4(2)$ & $4(3)$ & $4(4)$ \\
Property rights for women & 1 & 1 & $2(1)$ & $3(1)$ & $4(2)$ \\
Freedom of domestic movement for men & 1 & 2 & $3(2)$ & $4(2)$ & $4(2)$ \\
Freedom of domestic movement for women & 1 & 1 & $2(2)$ & $3(2)$ & $4(3)$ \\
Access to justice for men & 1 & 1 & $2(1)$ & $2(1)$ & $3(2)$ \\
Access to justice for women & 1 & 1 & $2(1)$ & $2(1)$ & $3(3)$ \\
Freedom from forced labor for men & & 1 & $2(1)$ & $3(2)$ & $4(3)$ \\
Freedom from forced labor for women & 1 & 1 & $2(1)$ & $3(2)$ & $3(3)$ \\
Freedom of discussion for men & & & 2 & $3(1)$ & $3(2)$ \\
Freedom of discussion for women & & & 2 & $3(1)$ & $3(2)$
\end{tabular}

Table 5 clearly suggests that the electoral component index is conditional on preexisting high levels of a number of civil liberties, both for men and women. For a country to achieve certain levels on the electoral index, the country needs high scores for the indicators of property rights, freedom of domestic movement, and freedom from forced labor for both men and women. The dependency is less strong, but still clear on the indicators of freedom of discussion and access to justice for both men and women. The results suggest that civil liberties for both men and women are important for a country to have competitive elections.

Table 6: Dependency table of civil liberty indicators on the electoral component index

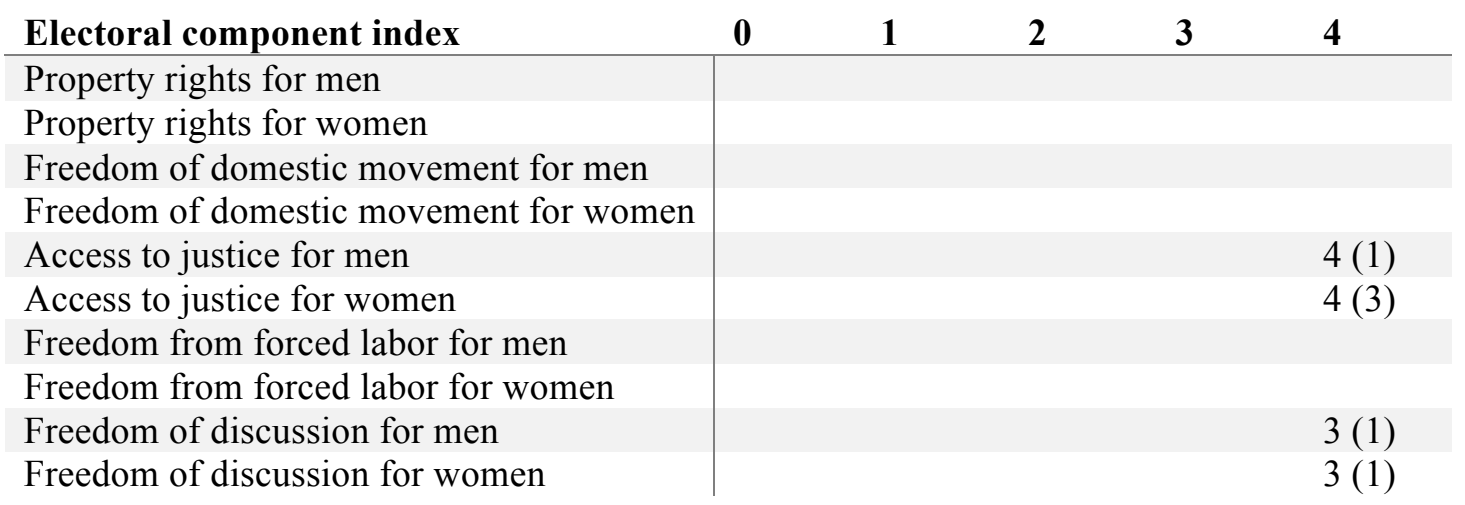

To rule out the possibility that the development of civil liberties may also depend on the quality of elections, that is, that the minimal values presented in Table 5 are due to correlations and not temporal dependencies, Table 6 shows the reversed descriptives to those in the previous table. The numbers in Table 6 are countries' minimal scores on the electoral component index when the country scores $0,1,2,3$, or 4 for these civil liberty indicators. The table shows that only few values of few civil liberties are dependent on the electoral component index. Only for the highest score of freedom of discussion and access to justice for both genders, the country's elections need to achieve certain levels of competitiveness. These figures 
suggest that free and fair elections are helpful for the development of certain civil liberties to the highest possible levels, but in most cases, it is the electoral principle of democracy that depends on civil liberties, not the other way around.

The frequency and dependency tables presented in Table 3 to Table 6 show the pairwise relationships in the data between the electoral index and civil rights indicators, and between male and female civil rights. The results suggest that civil rights for men tend to develop ahead of civil rights for women. However, as is also indicated in these tables, the advances in male civil rights do not constitute a sufficient condition for regime changes. Civil rights for men and women are both important and have both to reach certain levels before the country has free and fair elections. Regardless of the levels of male civil rights, if female civil rights are limited and have not achieved certain values, then it is difficult for a country to experience democratic transitions. To verify that these patterns are not due to the effects of confounding factors, we also utilize the conventional fixed-effect regression analysis to control for variables identified as crucial predictors of democratization. The results of the regression models are included in Appendix C, and show that both men's and women's rights are correlated with the emergence of competitive elections, even when the effects of economic development, income inequality, and oil production per capita, are controlled for.

After establishing the relationship between the electoral index and civil liberty indicators, we further investigate whether women's participation in civil society organizations constitutes a mechanism linking the improvement of civil rights and democratization. Table 7 lists the percentages of observations where the indicator of women's participation in CSOs has a value greater than the electoral component index, in comparison to observations where the values of the electoral index are greater. The table shows that in most cases, countries have a higher score on the indicator of women's participation than the electoral component index. It is likely that women's participation in the civil society tends to improve before the country's performance on the electoral index achieves an equivalent level.

Table 7: Relative frequency table of women's participation in civil society organizations and the electoral principle of democracy

Variable $A=$ Electoral component $\%$ when $B>\%$ when $B=\%$ when $B<$

\begin{tabular}{llll} 
index & $A$ & $A$ & $A$ \\
\hline Variable B: CSO women's participation & 56 & 25 & 19
\end{tabular}

Table 8 compares the levels of both male and female civil liberties with scores of the indicator of women's participation in CSO. The relative frequencies show that countries' scores 
on certain types of civil liberties for both genders, especially property rights, freedom of domestic movement, and freedom from forced labor, tend to be higher than their electoral component index. This pattern is less clear for other civil rights indicators. Table 9 and 10 further show the dependency analyses between women's involvement in civil society movement and civil liberties. Similar to Table 5 and 6, Table 9 documents, across all observed combinations, countries' minimal scores for the civil rights indicators when the country scores 0 , 1, 2, 3, or 4 on the indicator of women's CSO participation, while Table 10 includes the reverse scores. These two tables suggest that, in general, women's participation in CSO is dependent on the improvement of civil liberties for both genders to some extent. Only for the highest score of freedom of discussion and access to justice for both genders, does the country need to achieve certain levels on the civil society indicators. That is, in most cases, it is women's involvement in civil society movement that depends on civil liberties, not the other way around. However, these dependency relationships are not as strong as those between electoral democracy and civil liberties, shown in Table 4-6. In some cases, civil rights and women's involvement in civil society improve at the same time.

Table 8: Relative frequency table of civil liberties and women's participation in civil society organizations

$$
\begin{aligned}
\text { Variable } A=C S O \text { women's } & \% \text { when } B>\quad \% \text { when } B=A \quad \% \text { when } B<A \\
\text { participation } & A
\end{aligned}
$$

Variable $B$

Property rights for men $\quad 70$

Freedom of domestic movement for men $\quad 68$

Freedom of domestic movement for women 58

Property rights for women

A

Freedom from forced labor for men

Freedom from forced labor for women

Freedom of discussion for women

Freedom of discussion for men

Access to justice for men

Access to justice for women

$\begin{array}{lll}70 & 23 & 7.6 \\ 68 & 23 & 9.2 \\ 58 & 28 & 14 \\ 56 & 28 & 16 \\ 51 & 30 & 19 \\ 44 & 32 & 24 \\ 31 & 33 & 36 \\ 32 & 31 & 37 \\ 30 & 28 & 43 \\ 23 & 28 & 49\end{array}$


Table 9: Dependency table of CSO women's participation on civil liberties

\begin{tabular}{l|lllll} 
CSO women's participation & $\mathbf{0}$ & $\mathbf{1}$ & $\mathbf{2}$ & $\mathbf{3}$ & $\mathbf{4}$ \\
\hline Property rights for men & 1 & $1(1)$ & $2(1)$ & 1 & $4(2)$ \\
Property rights for women & 1 & 1 & 1 & 1 & $2(1)$ \\
Freedom of domestic movement for men & 1 & 2 & $2(1)$ & $2(1)$ & $3(1)$ \\
Freedom of domestic movement for women & 1 & 2 & $2(1)$ & $2(1)$ & $3(1)$ \\
Access to justice for men & 1 & 1 & $1(1)$ & 1 & $1(1)$ \\
Access to justice for women & 1 & 1 & $1(1)$ & 1 & $1(1)$ \\
Freedom from forced labor for men & & 1 & 1 & 2 & $2(1)$ \\
Freedom from forced labor for women & 1 & 1 & 1 & $1(1)$ & $2(1)$ \\
Freedom of discussion for men & & & 1 & 2 & 3 \\
Freedom of discussion for women & & 1 & 1 & 1 & 1
\end{tabular}

Table 10: Dependency table of civil liberty indicators on CSO women's participation

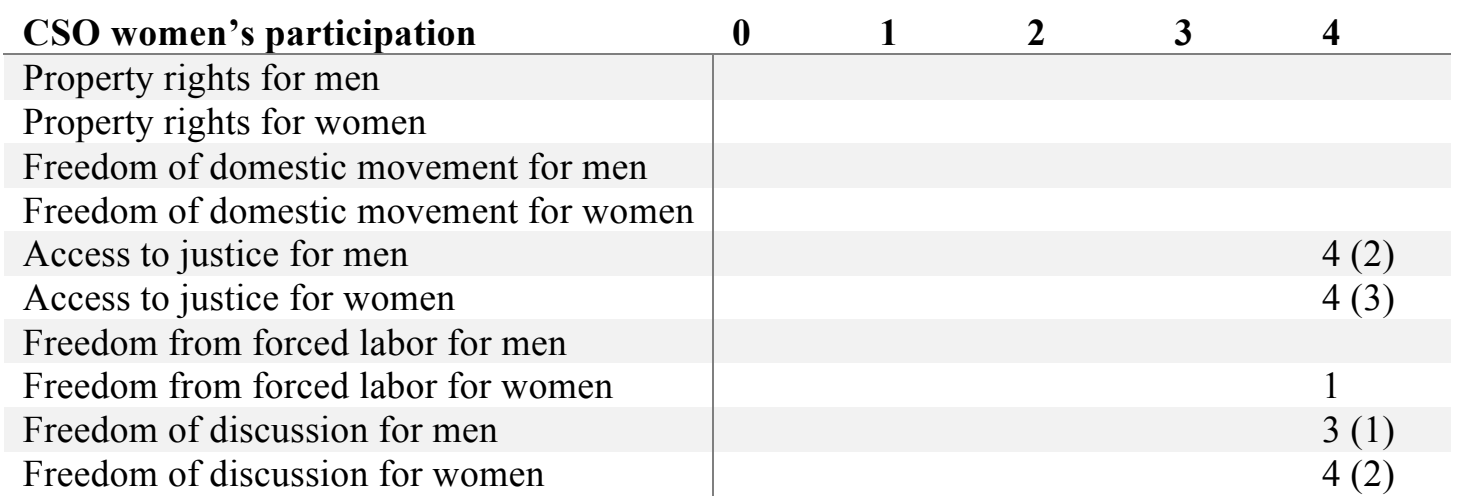

The frequency and dependency analyses in Table 7 to Table 10 suggest that women have to be sufficiently involved in civil society organizations before the country has free and fair elections. In addition, the improvement of certain civil rights for both men and women, especially property rights and freedom of domestic movement, constitutes an important condition for women being active in the public sphere. The analyses in this section establish the likely sequential relationship between the improvement of civil rights, women's participation in CSOs, and electoral democracy.

\subsection{Graphical Presentation of Changes}

The frequency and dependency analyses suggest that countries tend to score higher for both male and female civil rights than on the electoral index, and that the electoral index is dependent on pre-existing civil rights, but not the other way around. To further verify the direction of changes, and ensure that our results imply a development in male and female civil liberties before the establishment of free and fair elections, we plot all changes for the electoral index and 
different civil right indicators. Figure 2 shows all the observed pathways of changes, and Figure 3 compares the frequencies of the observed and the expected pathways. The figures for access to justice and forced labor are included in Appendix D.

The figures are consistent with our hypotheses that civil liberties for both men and women tend to develop first, before the emergence of free and fair elections. Similar to what frequency and dependency analyses show, across the different types of civil rights, the quality of elections especially depends on high scores for property rights and freedom of domestic movement, and, to a lesser degree, on certain levels of freedom of discussion ${ }^{4}$. Figure 3 also indicates that the reform paths where the civil rights are strengthened first and competitive elections then start to take place, are the most common reform paths, based on the comparison between the observed and expected frequencies.

Figure 4 shows all the observed changes for the electoral index and the indicator of women's participation in CSOs. Consistent with the observations in the frequency analysis, the involvement of women in civil society movements tends to take place before the establishment of electoral democracy. Figure 5 includes the pathways of changes for the civil society indicator and different civil rights indicators, and the figure further suggests that women's participation in CSOs is especially conditional on the improvement of property rights and freedom of domestic movement for both genders. Note, however, that the figures indicate an initial increase in electoral democracy at very low levels of women's participation in civil society movements. Based on the graphical approach and the results of frequency and dependency analyses, the likely sequential relationships and the direction of changes between liberal rights, the strength of civil society, and electoral democracy are established. Liberal rights of both men and women have to be strengthened first, and the advance in certain rights especially leads to women's increased involvement in movements, which is consequently helpful for electoral democracy to arise.

\subsection{Bayesian Dynamical Systems Analysis}

To model changes in values of civil rights indicators and the electoral component indicators at different levels, and identify potential non-linear relationships between them, we adopt the Bayesian dynamical systems approach. The equations with the highest Bayes' factors for property

\footnotetext{
${ }^{4}$ We also conducted sequence analyses to explore the temporal relationships between different types of civil rights. The results are shown in Appendix B. They suggest that property rights for both genders tend to develop first, which is followed by the improvement of freedom of domestic movement and freedom from forced labor for both men and women. Freedom of discussion and access to justice then change later, and are followed by the emergence of free and fair elections.
} 
rights (variable $\mathrm{x}$ ) and the electoral component index (variable y) are the following for male property rights:

$$
\begin{aligned}
& d x=\left(0.063-0.0012 \frac{1}{x}-0.067 x\right) y \\
& d y=\left(0.09-0.35 y+0.25 y^{2}\right) y+0.017 x^{3}
\end{aligned}
$$

And for female property rights:

$$
\begin{aligned}
& d x=(0.046-0.049 x) y \\
& d y=\left(0.088-0.35 y+0.25 y^{2}\right) y+0.023 x^{3}
\end{aligned}
$$

Figure 6 plots the trajectories given by the equations. For illustration and comparison, the figure also shows actual trajectories in the past for six arbitrarily selected countries, as examples. The results suggest that, at low levels of both variables, the electoral index can grow roughly independently of property rights. However, as the index reaches values higher than 0.34 , it requires more and more property rights, for both men and women, in order to increase. With high scores on the property rights indicators, the electoral index cannot stay at low values; while with low scores on the property rights indicators, it is not possible for the electoral index to remain high. While increases in the electoral component index depend on property rights, and while property rights grow linearly with the electoral component index, the direction does not depend on it. In addition, countries are estimated to pass approximately through the point $(0.9$ on the male property rights indicator, 0.5 on the electoral index). The estimated dynamics between the property rights for women and the electoral index are quite similar to those between the indicator for men and the electoral index. However, the results suggest that property rights for women seem to have slightly greater impacts on the index.

The equations with the highest Bayes' factors for freedom of discussion (variable $\mathrm{x}$ ) and the electoral component index (variable y) are the following for male freedom of discussion:

$$
\begin{aligned}
& d x=\left(0.057+0.041 y^{2}-0.094 x\right) y \\
& d y=\left(0.12-0.46 y+0.32 y^{2}\right) y+0.04 x^{3}
\end{aligned}
$$

And for female freedom of discussion:

$$
\begin{aligned}
& d x=\left(0.052+0.036 y^{2}-0.085 x\right) y \\
& d y=\left(0.1-0.44 y+0.31 y^{2}\right) y+0.044 x^{2}
\end{aligned}
$$


Figure 7 plots the trajectories given by the equations. We have also here included examples of actual trajectories. The dependence of the electoral index on freedom of discussion is similar to property rights, but freedom of discussion also depends on the electoral index in order to surpass 0.5 .

If we include both male and female civil rights together with the electoral component index in the same dynamical system, then the rate of change in both male and female civil rights depends roughly linearly on the electoral component index, as in the separate systems. For the electoral component index, female rights appear to be more important than male rights. The equations with the highest Bayes' factors include only the index itself and female rights as affecting the rate of change. Male and female rights, however, are highly correlated, so this fact should not be interpreted as male rights not being important, but it suggests that female rights are somewhat better predictors of increased in the electoral component index. Also, men's freedom of discussion improves more with higher values in women's freedom of discussion, while the dynamical system shows no evidence of the opposite.

The equations for female $(x)$ and male $(y)$ property rights and the electoral component index $(z)$ are:

$$
\begin{aligned}
& d x=(0.046-0.049 x) z \\
& d y=\left(0.063-0.067 y-0.0012 \frac{1}{y}\right) z \\
& d z=\left(0.088-0.35 z+0.25 z^{2}\right) z+0.023 x^{3}
\end{aligned}
$$

The equations for female $(\mathrm{x})$ and male $(\mathrm{y})$ freedom of discussion and the electoral component index $(\mathrm{z})$ are:

$$
\begin{aligned}
& d x=\left(0.052-0.085 x+0.036 z^{2}\right) z \\
& d y=(0.08-0.19 y+0.12 x y) z \\
& d z=\left(0.1-0.44 z+0.31 z^{2}\right) z+0.044 x^{2}
\end{aligned}
$$

The dynamic system analyses suggest that while all the previous approaches point out the dependency of the electoral index on civil liberty indicators, there is some non-linearity between them. The more nuanced complexities involved in this dependency relationship require further studies to illustrate. 


\section{Concluding Discussion}

This paper departed by discussing the theoretical reasons why women's rights may matter for a country's successful transitions toward democratic rule. We pointed specifically to macro-level factors regarding gender inequality in rights and the cost of repression as well as micro-level aspects of how women's labor market involvement produce civic skills that affect their capacity for political participation as well as how women's organization in movements for democratic reform may be crucial during transitions. We conducted an empirical test of this reasoning that is more comprehensive than previous studies in this vein of research. Expert assessments covering over 160 states over the years 1900-2012 allow us to make inferences that span over a longer period of time and across more countries than in earlier research.

In this paper we offer systematic analyses on the oft-mentioned relationship between political liberalization and democratization. From a gendered aspect, we especially point out the importance of women's civil rights. Utilizing sequence analysis approaches focusing on the temporal relationships between variables, and a novel cross-sectional time-series dataset including disaggregated measures of various dimensions of democracy, we show that both men's and women's liberal rights are essential conditions for democratization to take place. Men's civil rights attain high values sooner than women's civil rights. However, women's civil rights are somewhat predictive of possible improvement in men's civil rights, and regardless of the levels of male civil rights, if female civil rights are limited, it is difficult for a country to experience democratic transitions. In addition, the improvement of certain liberal rights for both genders leads to women's increased involvement in the civil society, which is helpful for electoral democracy to take place. We find that this pattern is robust also when analyzing subsets of this data, such as time periods with the earliest democracies. The results suggest we should put more effort into exploring women's participation in the transition process.

Other potential mechanisms through which the advances in women's rights lead to a successful transition, such as women's participation in the formal labor force, require further studies to verify. For the moment we are unable to say much about the mediating effect from some key variables that we mention in our argument. We currently show that women's political movements tend to arise after the improvement of certain liberal rights and before the electoral component index achieves its maximum value, and constitute a mechanism in this process. However, due to lack of data availability, we cannot examine how women's inclusion in the labor market mediates the effect from women's rights on democratic status. 
These findings have implications for both researchers and policy-makers. We point towards the necessary role of rights for women. In doing so, the findings suggest that influential modernization writings - stressing the role of economic development in democratization processes - and the theoretical discussion on the evolution of different rights (cf. Marshall 1950; Janosky 1998), generally neglecting rights of different sexes, may partly have been misinformed. Our findings contradict some of the more influential theories of democratization, holding that economic development is a necessary condition in this process (see e.g. Przeworski and Limongi 1997). Rather, our findings suggests that there are important gendered dimensions of this process, and especially that the sequencing of rights to women is crucial. The gendered feature of this process has, until now, rarely been studied in a comparative perspective. In this sense, we confirm some of the insights gained by qualitative studies of women's organization in democratization processes.

Pertaining to a discussion relevant for policy-makers, the results hold the promise to improve our understanding of current challenges for further democratization of regions where women's rights are weak. This may, for instance, provide insights into why so few countries were successfully democratized during the so-called Arab spring: during these years only one country, Tunisia, upheld democratic gains. While the future of countries in this region is difficult to predict, the democracy scholar Larry Diamond recently noted: "Tunisia remains full of promise. Alone among the Arab Spring states, it has achieved a remarkable level of political compromise among secular parties" (Diamond 2015). As Figure 8 shows, based on the averages of the five civil liberty indicators for women, Tunisia was, at the same time, the country in the region with the most rights for women.

For further analyses, we expect to develop a refined way to draw inferences from our approaches, and examine cases with similar sequences to see whether they share some features. Future research could benefit from further disentangling the sequential relationship between rights among men and women and the democratic standing of a country. We especially invite a further use of multi-method research that combines the strength of different approaches and hope that other researchers may continue to advance the discussion we hope to engage in. 
Figure 2: The pathways of changes in civil liberty indicators and the electoral index.
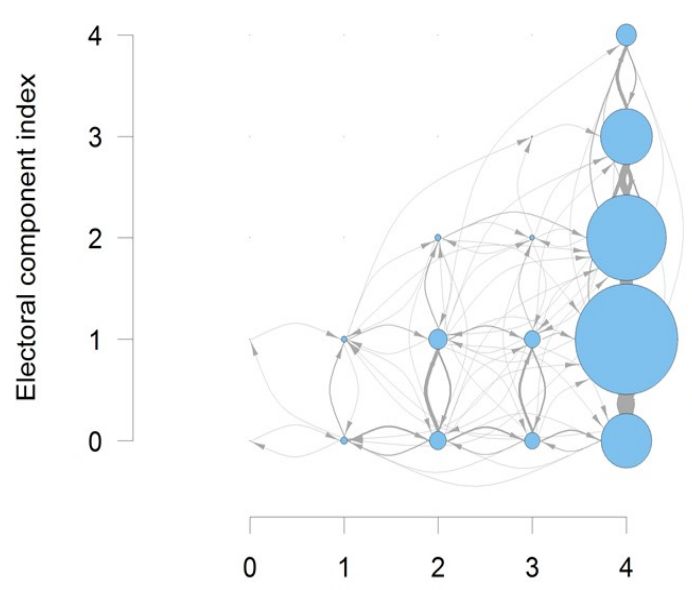

Property rights for men
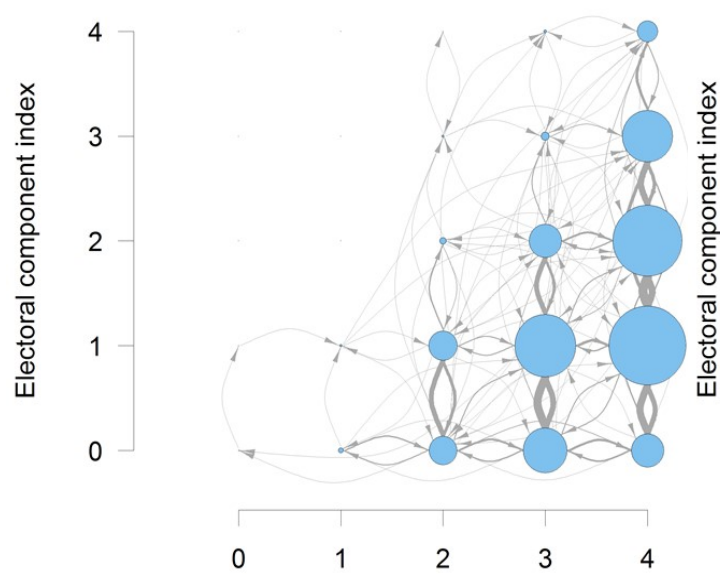

Freedom of domestic movement men

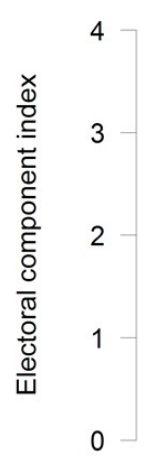

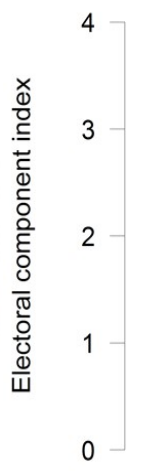

$$
0
$$

Property rights for women
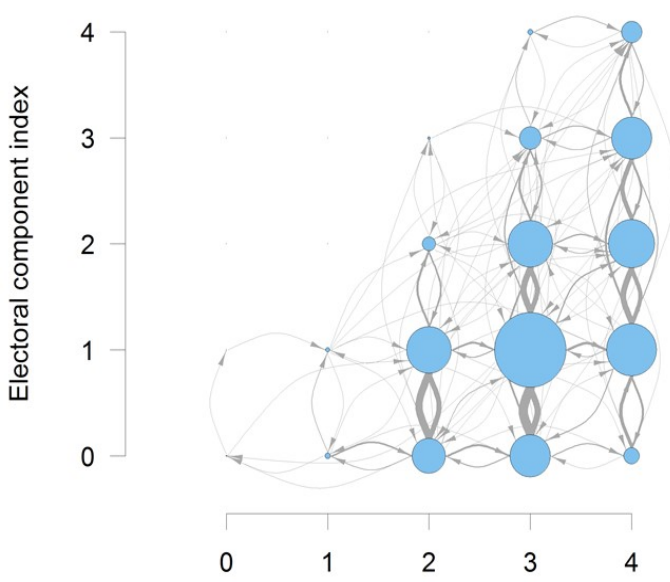

Freedom of domestic movement women
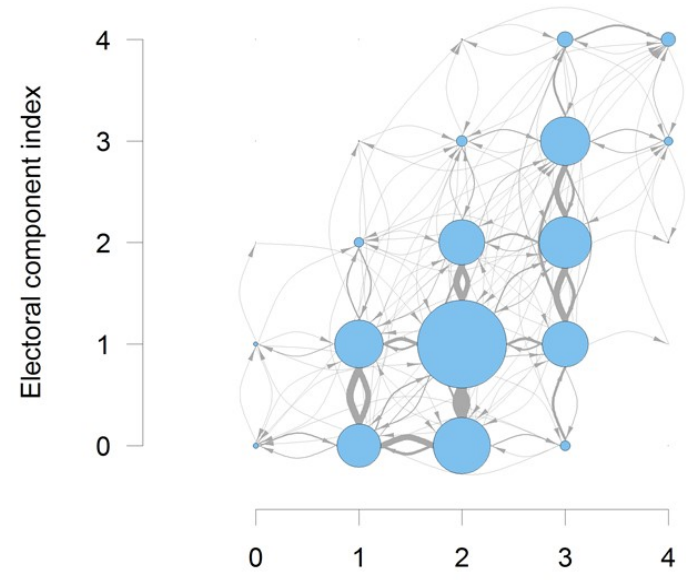

Freedom of discussion for women 
Figure 3: Comparison between observed and expected pathways of changes in civil liberty indicators and the electoral index. "Ridges" (positive numbers) indicate reform paths that are more popular than expected by variable distributions alone, while "rifts" (negative numbers) indicate the opposite.
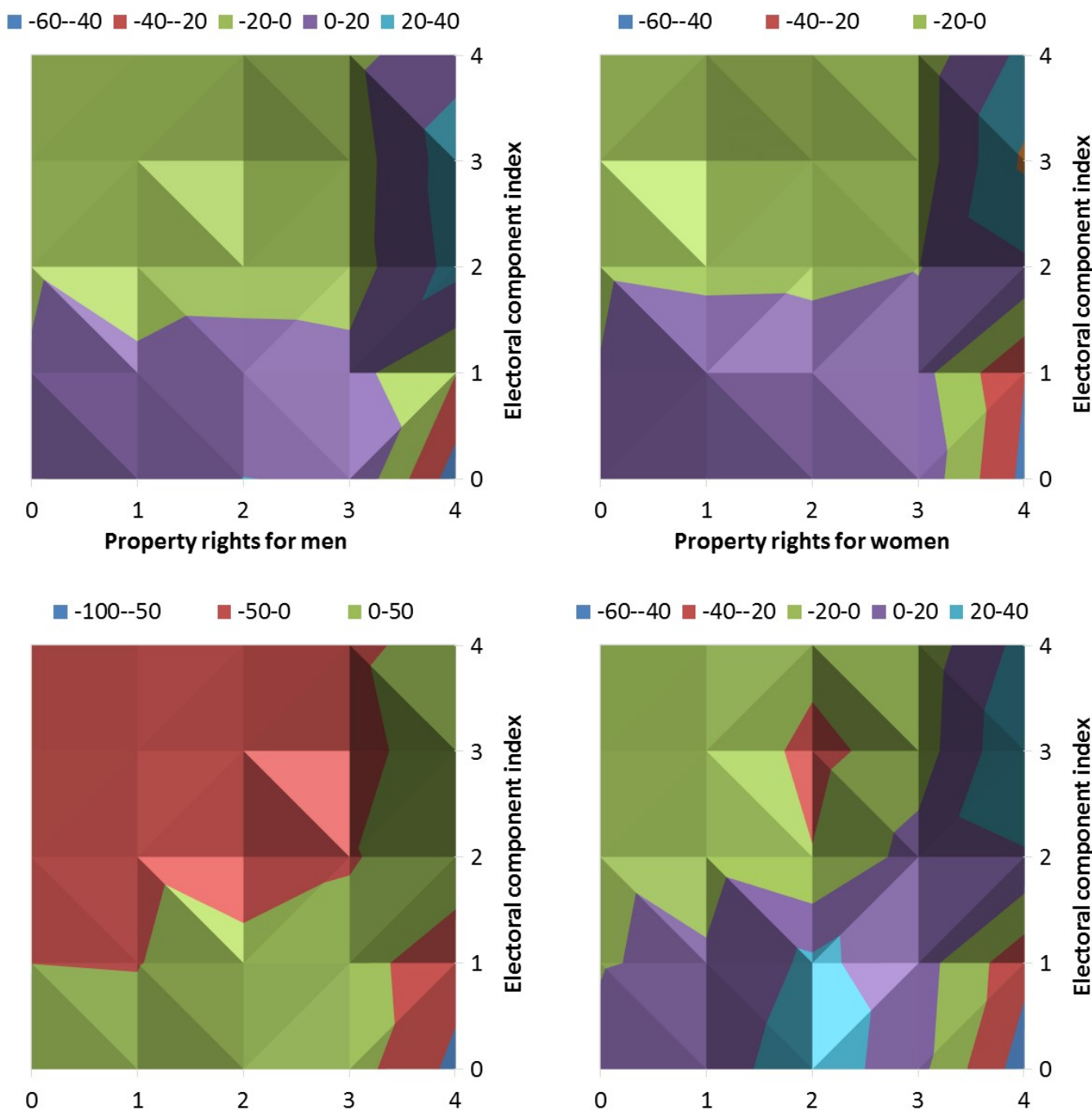

$--60--40 \square-40--20 \square-20-0 \square 0-20 \square 20-40$

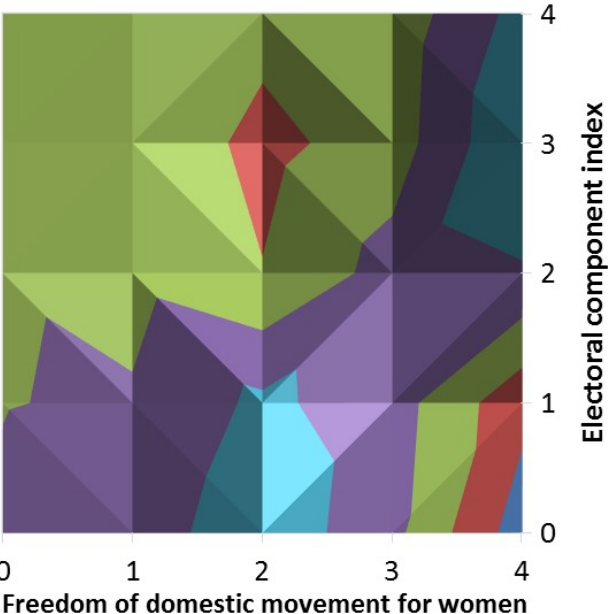

Freedom of domestic movement for men
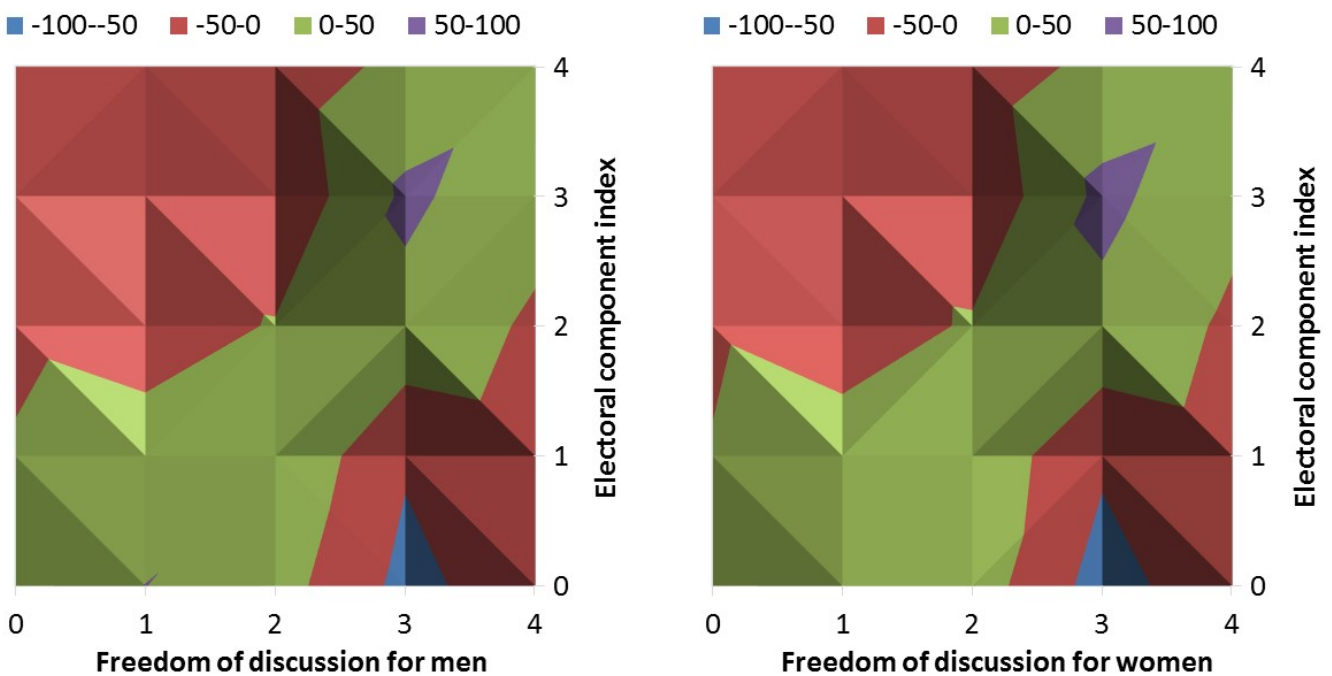
Figure 4: The pathways of changes in women's participation in CSOs and the electoral index.

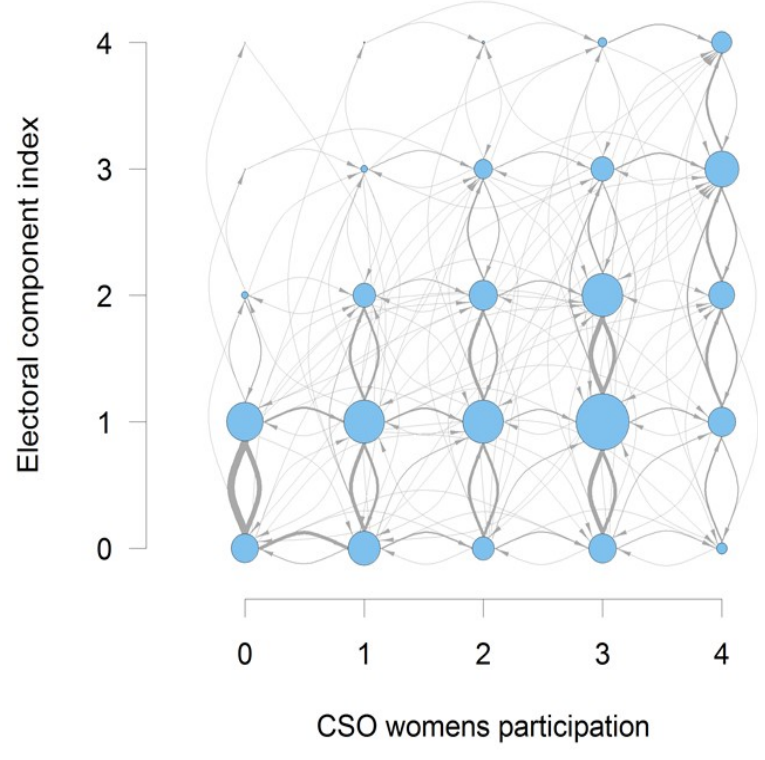


Figure 5: The pathways of changes in civil liberties and women's participation in CSOs
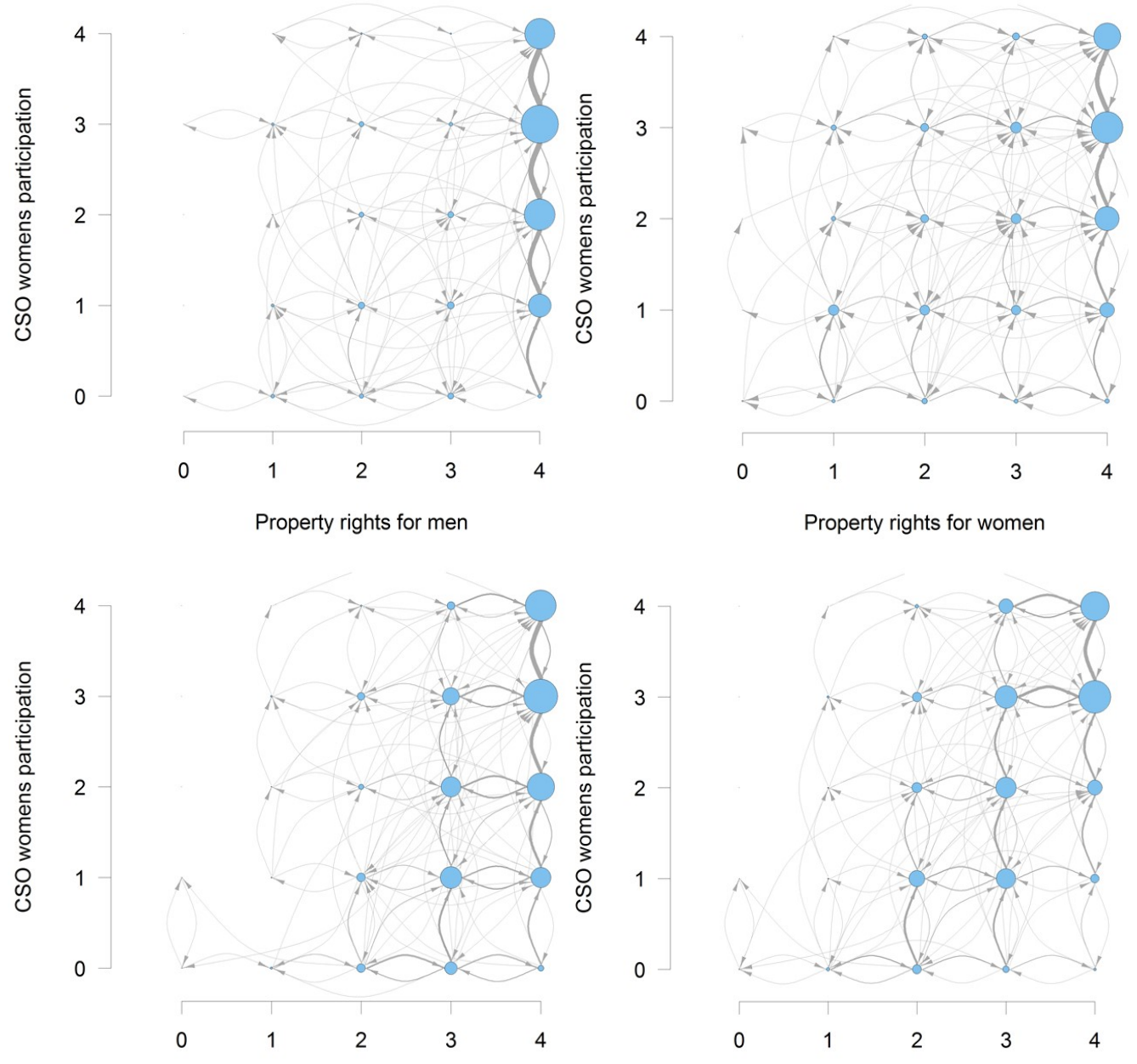

Freedom of domestic movement for men

Freedom of domestic movement for women
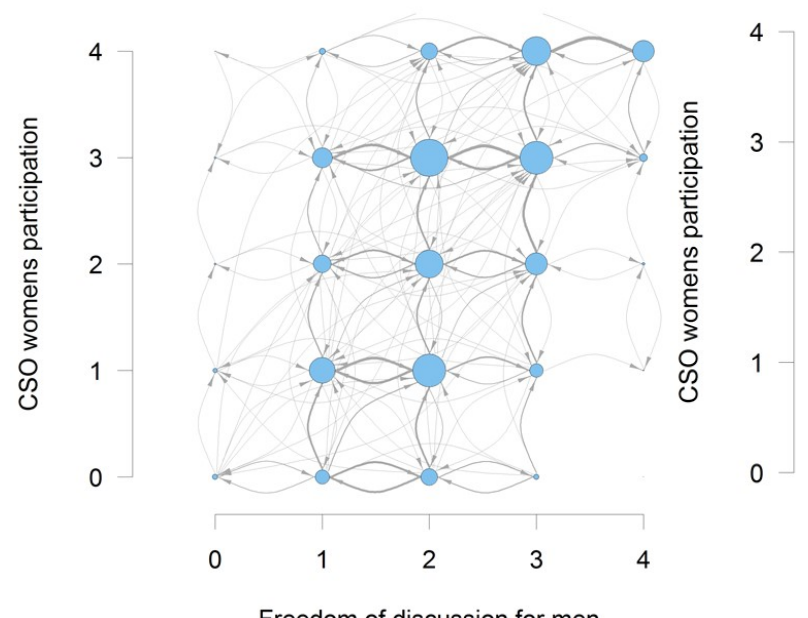

Freedom of discussion for men

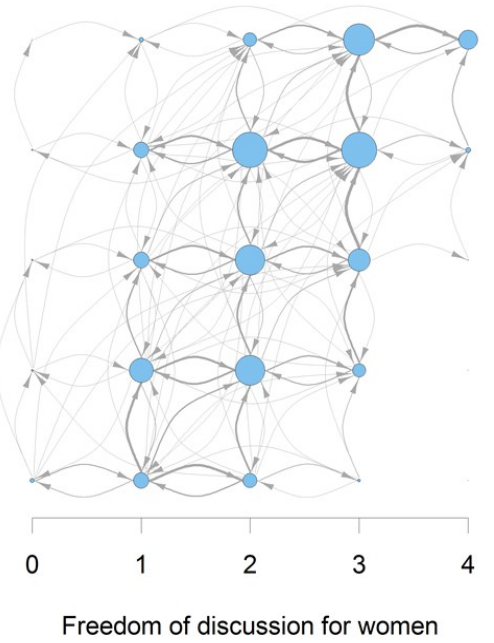


Figure 6: Phase diagrams given by the Bayesian dynamical systems for property rights and the electoral index
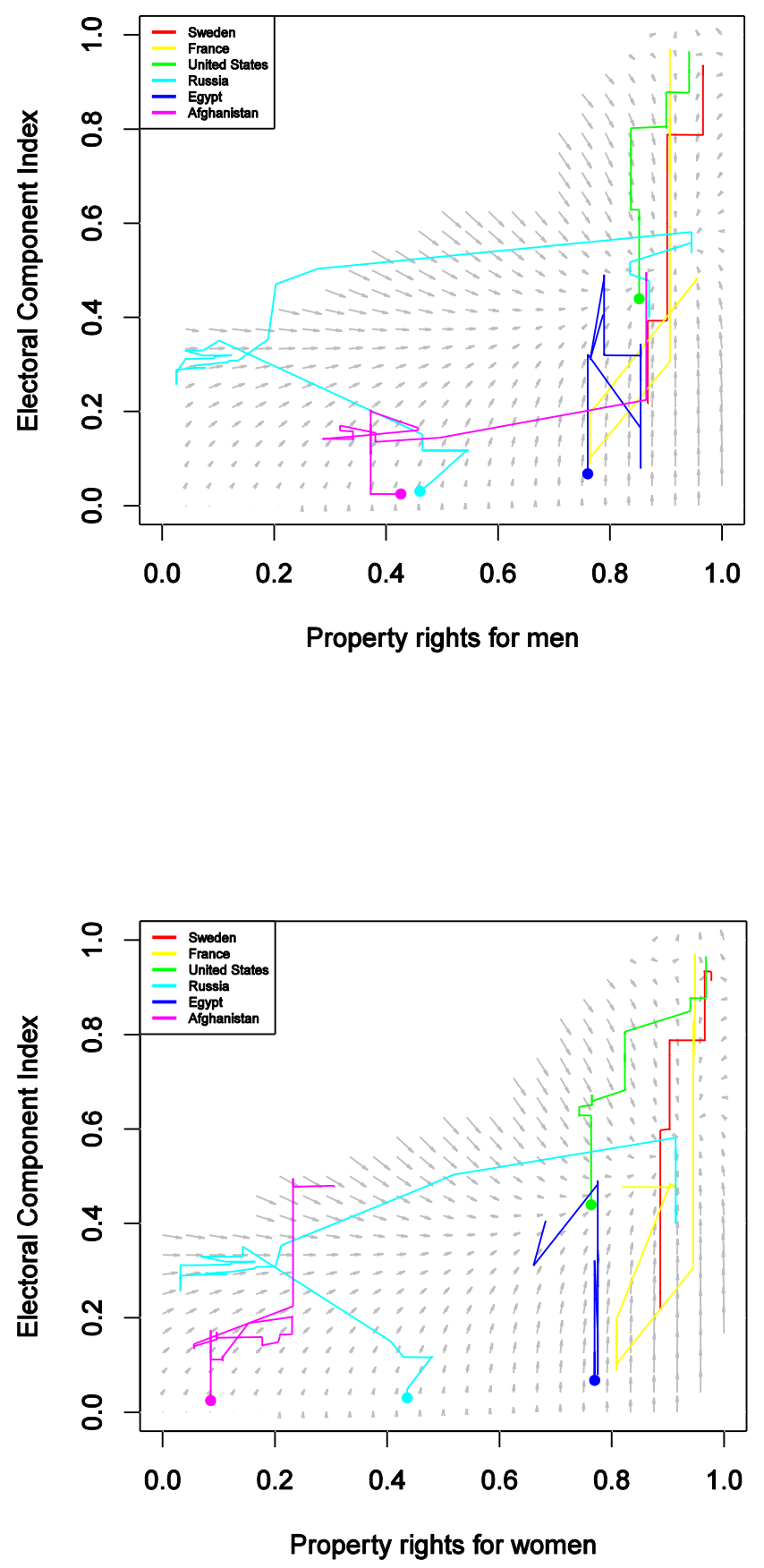
Figure 7: Phase diagrams given by the Bayesian dynamical systems for freedom of discussion and the electoral index
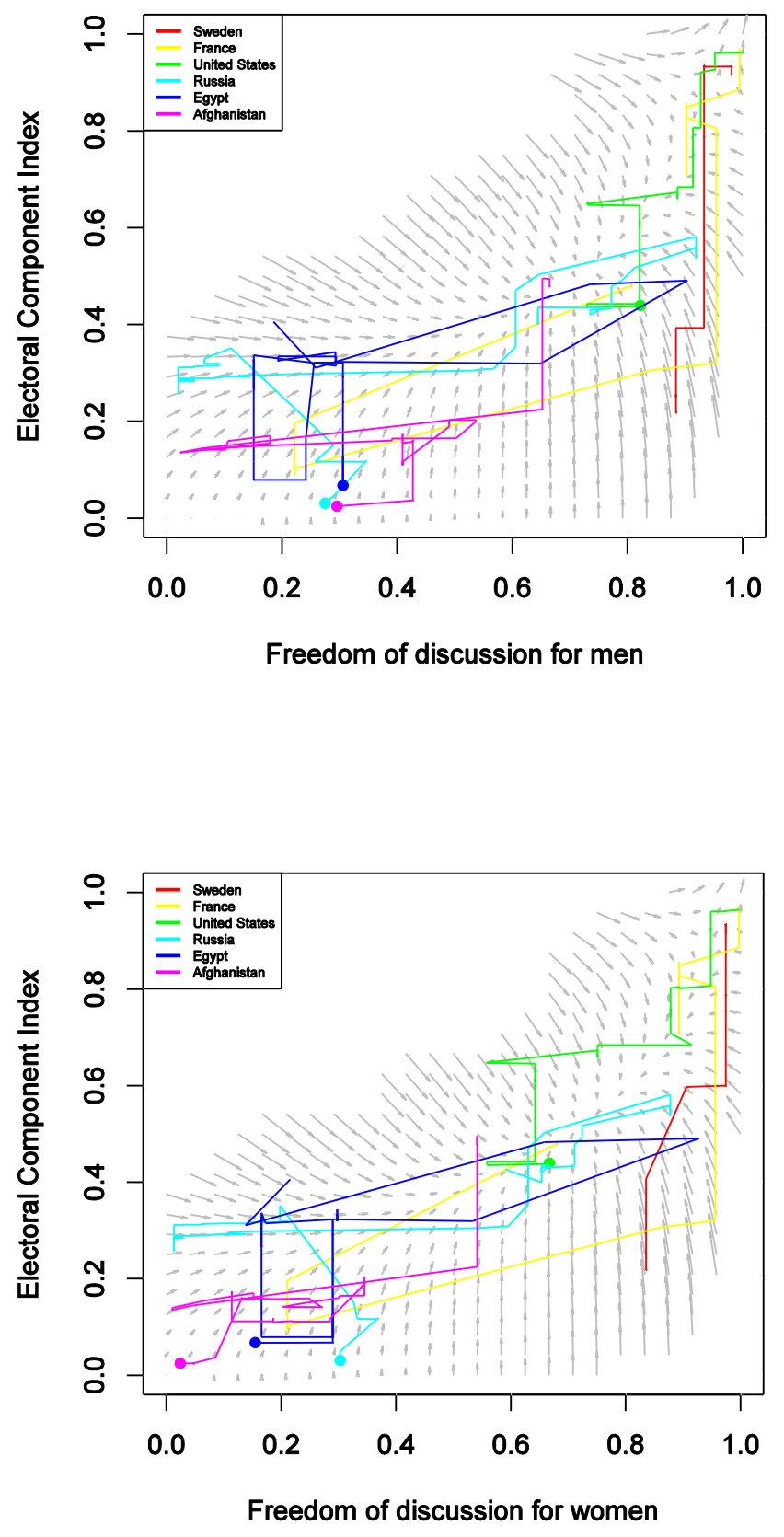
Figure 8: Women's liberal rights in Arab Spring countries

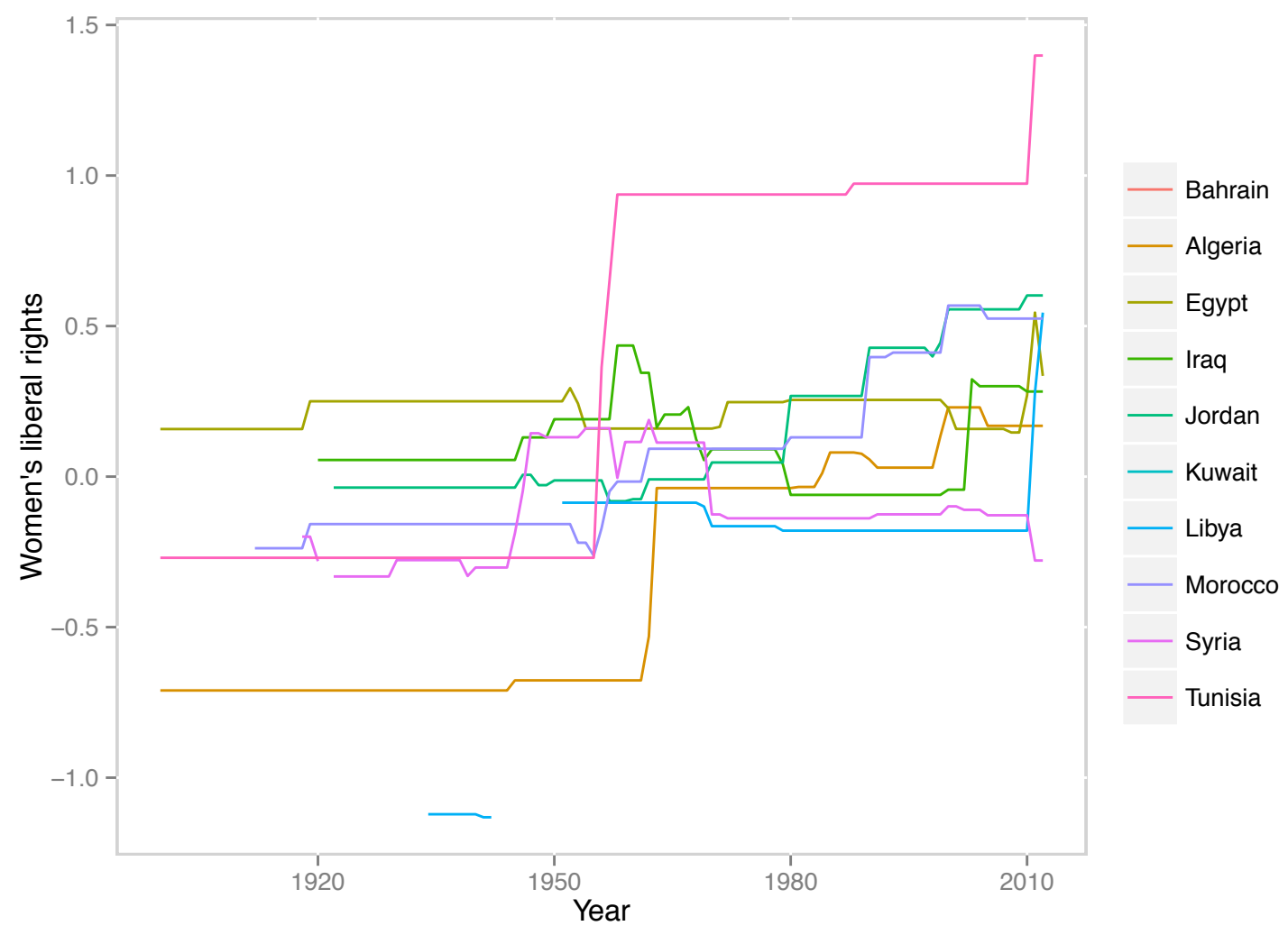




\section{References}

Abbott, Andrew. 1995. "Sequence Analysis: New Methods for Old Ideas." Annual review of sociology 21: 93-113.

Abbott, Andrew and Angela Tsay. 2000. "Sequence Analysis and Optimal Matching Methods in Sociology Review and Prospect." Sociological Methods \& Research 29(1): 3-33.

Acemoglu, Daron and James A. Robinson. 2001. A Theory of Political Transitions. American Economic Review 91(4): 938-963.

Acemoglu, Daron and James A. Robinson. 2006. Political Origins of Dictatorship and Democracy. New York: Cambridge University Press.

Acemoglu, Daron, Simon Johnson, James A. Robinson, and Pierre Yared. 2008. "Income and Democracy." American Economic Review 98(3): 808-842.

Acemoglu, Daron, Simon Johnson, James A. Robinson, and Pierre Yared. 2009. "Reevaluating the Modernization Hypothesis." Journal of Monetary Economics 56: 1043-1058.

Agresti, Alan. 2013. Categorical Data Analysis. 3rd Edition. Hoboken, NJ: John Wiley \& Sons.

Arat, Yeflim. 1994. “Toward a Democratic Society: The Women's Movement in Turkey in the 1980s." Women's Studies International Forum 17(2-3): 241-48.

Barro, Robert J. 1999. Determinants of Democracy. "Journal of Political Economy." 107(6): 158-83.

Beetham, David. 1999. Democracy and Human Rights. Cambridge: Polity Press.

Boix, Carles. 2003. Democracy and Redistribution. New York: Cambridge University Press.

Boix, Carles and Susan C. Stokes. 2003. "Endogenous Democratization." World politics 55(4): 51749.

Casper, Gretchen and Matthew C. Wilson. 2015. "Using Sequences to Model Crises." Political Science Research and Methods 3(2): 381-397.

Chacón, Mario L. 2012. “A Theory of Competitive Authoritarian Elections.” Work in progress. Avainlable online,

http://www.mariochacon.com/uploads/2/4/9/7/24976328/theorycaelectionsmchacon.pdf

Chhibber, Pradeep. 2002. "Why Are Some Women Politically Active? The Household, Public Space, and Political Participation in India." International Journal of Comparative Sociology 43(3-5): 409-29.

Coppedge, Michael, John Gerring, David Altman, Mikael Bernhard, Steven Fish, Alan Hicken, Matthew Kroenig, Staffan Lindberg, Kelly McMann, Pamela Paxton, Holli A. Semetko, SvenErik Skaaning, Jeffrey Staton and Jan Teorell. 2011. "Conceptualizing and Measuring Democracy: A New Approach.” Perspectives on Politics 9(2): 247-267. 
Coppedge, Michael, John Gerring, Staffan I. Lindberg, Jan Teorell, David Altman, Michael Bernhard, M. Steven Fish, Adam Glynn, Allen Hicken, Carl Henrik Knutsen, Kelly McMann, Daniel Pemstein, Svend-Erik Skaaning, Jeffrey Staton, Eitan Tzelgov, Yi-ting Wang, and Brigitte Zimmerman. 2015a. "Varieties of Democracy: Dataset v4." Varieties of Democracy (V-Dem) Project.

Coppedge, Michael, John Gerring, Staffan I. Lindberg, Jan Teorell, David Altman, Michael Bernhard, M. Steven Fish, Adam Glynn, Allen Hicken, Carl Henrik Knutsen, Kelly McMann, Daniel Pemstein, Svend-Erik Skaaning, Jeffrey Staton, Eitan Tzelgov, and Yi-ting Wang. 2015b. "Varieties of Democracy: Codebook v4." Varieties of Democracy (V-Dem) Project.

Coppedge, Michael, John Gerring, Staffan I. Lindberg, Jan Teorell, David Altman, Michael Bernhard, M. Steven Fish, Adam Glynn, Allen Hicken, Carl Henrik Knutsen, Kelly McMann, Daniel Pemstein, Svend-Erik Skaaning, Jeffrey Staton, Eitan Tzelgov, Yi-ting Wang, and Brigitte Zimmerman. 2015c. "Varieties of Democracy: Methodology v4." Varieties of Democracy (V-Dem) Project.

Davenport, Christian. 2007. "State Repression and Political Order." Annual Review of Political Research 10: 1-23.

Diamond, Larry. 2015a. "Facing Up to the Democratic Recession." Journal of Democracy 26(1): 141-155.

Diamond, Larry. 2015b. Tunisia Is Still a Success. The Atlantic, March 23rd 2015. Available online at http://www.theatlantic.com/international/archive/2015/03/tunisia-is-still-asuccess-terrorist-attack/388436/

Fallon, Kathleen, Liam Swiss, Jocelyn Viterna. 2012. "Resolving the Democracy Paradox: Democratization and Women's Legislative Representation in Developing Nations, 1975 to 2009." American Sociological Review 77(3): 380-408.

Fish, Steven M. 2002. Islam and Authoritarianism. World politics 55(1): 4-37.

Frey, Scott R. and Carolyn Field. 2000. "The Determinants of Infant Mortality in the Less Developed Countries: A Cross-National Test of Five Theories." Social Indicators Research 52(3): 215-34.

Gauthier, Jacques-Antoine, Eric D. Widmer, Philip Bucher, Cédric Notredame. 2010. "Multichannel sequence analysis applied to social science data." Sociological Methodology 40(1): 138.

Greenberg, Anna. 2000. “Deconstructing the Gender Gap.” Working Paper, John F. Kennedy School of Government, Harvard University. 
Houle, Christian. 2009. "Inequality and democracy: Why inequality harms consolidation but does not affect democratization." World Politics 61(4): 589-622.

Inglehart, Ronald, Pippa Norris, and Christian Welzel. 2002. "Gender Equality and Democracy." Comparative Sociology 1(3): 321-45.

Iversen, Torben and Francis Rosenbluth. 2006. "The Political Economy of Gender: Explaining Cross-National Variation in the Gender Division of Labor and the Gender Voting Gap." American Journal of Political Science 50(1): 1-19.

Jaquette, Jane S. 2001. "Regional Differences and Contrasting Views." Journal of Democracy 12(3): 11-125.

Janosky, Thomas. 1998. Citizenship and civil society. Cambridge: Cambridge University Press.

Jansson, Fredrik, Patrik Lindenfors, and Mikael Sandberg. 2013. "Democratic Revolutions as Institutional Innovation Diffusion: Rapid Adoption and Survival of Democracy." Technological Forecasting and Social Change 80(8): 1546-1556.

Jowett, Matthew. 2000. "Safe Motherhood Interventions in Low-Income Countries: An Economic Justification and Evidence of Cost Effectiveness." Health policy 53(3): 201-28.

Lindenfors, Patrik, Fredrik Jansson and Mikael Sandberg. 2011. "The cultural evolution of democracy: saltational changes in a political regime landscape.” PLoS ONE 6: e28270

Linz, Juan J., and Alfred C. Stepan. 1996. Problems of Democratic Transition and Consolidation. Baltimore: JHU Press.

Lipset Phillip. S. 1959. "Some Social Requisites of Democracy: Economic Development and Political Legitimacy." American Political Science Review 53: 69-105.

Marshall, Thomas. 1950. Citizenship and social class. Cambridge: Cambridge University Press

Matland, Richard E. 1998. “Women's Representation in National Legislatures: Developed and Developing Countries.” Legislative Studies Quarterly 23(1): 109-125.

Mill, John S. 1869. The Subjection of Women. London: Longmans, Green, Reader \& Dyer.

Moghadam, Valentine M. 2004. The Gender of Democracy: The Link Between Women's Rights and Democratization in the Middle East. Carnegie Endowment for International Peace. Published online July 20th http://carnegieendowment.org/2008/08/20/gender-of-democracy-linkbetween-women-s-rights-and-democratization-in-middle-east/fmkc

Moghadam, Valentine M. 2008 Democracy and Women's Rights: Reflections on the Middle East and North Africa. Presented at International Seminar "Comparative Studies on Family Democratization and Socio-Politics” Buenos Aires, 24-26 September 2008. 
Moghadam, Valentine M. 2010. Gender, politics and women's empowerment in (eds) Leicht, Kevin T. and J. Craig Jenkins. Handbook Of Politics: State And Society In Global Perspective. Handboooks Of Sociology And Social Research. New York: Springer.

Moghadam, Valentine M. 2013. "What is democracy? Promises and perils of the Arab Spring." Current Sociology 61(4): 393-408.

Moore, Barrington. 1966. Social Origins of Dictatorship and Democracy: Lord and Peasant in the Making of the Modern World. Boston: Beacon Press.

Morrison, Andrew. R., Dhushyanth Raju and Nistha Sinha. 2007. "Gender Equality, Poverty and Economic Growth.” World Bank policy research working paper no. 4349.

Paxton, Pamela, Melanie M. Hughes, Jennifer L. Green. 2006. “The International Women's Movement and Women's Political Representation, 1893-2003." American Sociological Review 71: 898-920.

Paxton, Pamela, Melanie M. Hughes, Matthew A. Painter. 2010. "Growth in women's political representation: A longitudinal exploration of democracy, electoral system and gender quotas." European Journal of Political Research 49: 25-52.

Pemstein, Daniel, Eitan Tzelgov, Yi-ting Wang. 2015. "Evaluating and Improving Item Response Theory Models for Cross-National Expert Surveys.” V-Dem Working Paper 2015:1.

Przeworski, Adam and Fernando Limongi. 1997 "Modernization: Theories and Facts". World Politics 49(2): 155-183.

Przeworski, Adam. 1991. Democracy and the Market. New York: Cambridge University Press.

Ragin, Charles C. 1987. The Comparative Method: Moving Beyond Qualitative and Quantitative Strategies. Berkeley: University of California Press.

Ranganathan Shyam, Viktoria Spaiser, Richard P. Mann, David J. T. Sumpter. 2014a. "Bayesian Dynamical Systems Modelling in the Social Sciences." PLoS ONE 9(1): e86468.

Ranganathan Shyam, Viktoria Spaiser, Richard P. Mann, David J. T. Sumpter. 2014b. bdynsys: Bayesian Dynamical System Model. $R$ package version 1.3. http://CRAN.Rproject.org $/$ package $=$ bdynsys

Rihoux, Benoít and Charles C. Ragin. 2008. Configurational Comparative Methods: Qualitative Comparative Analysis. Thousand Oaks: SAGE Publications, Inc.

Ross, Michael L. 2008. “Oil, Islam, and Women.” American Political Science Review 102(1): 108-123. Sanborn, Howard and Clayton L. Thyne. 2014. "Learning Democracy: Education and the Fall of Authoritarian Regimes.” British Journal of Political Science 44(4): 773-97. 
Schlozman, Kay L., Nancy Burns, and Sidney Verba. 1999. “'What Happened at Work Today?': A Multistage Model of Gender, Employment, and Political Participation." Journal of Politics 61(1): 29-53.

Sillén-Tullberg, Birgitta. 1993. "The effect of biased inclusion of taxa on the correlation between discrete characters in phylogenetic trees." Evolution 47: 1182-1191.

Spaiser Viktoria, Shyam Ranganathan, Richard P. Mann, David J. T. Sumpter. 2014. "The Dynamics of Democracy, Development and Cultural Values.” PLoS ONE 9(6): e97856.

Stockemer, Daniel and Maeva Byrne. 2012. “Women's Representation around the World: The Importance of Women's Participation in the Workforce.” Parliamentary Affairs 65(4): 802-821.

Tocqueville, Alexis de. 1835. Democracy in America. Translated by Henry Reeve. Charlottesville: University of Virginia.

Tripp, Aili M. 2001. “The New Political Activism in Africa.” Journal of Democracy 12 (3): 141-155.

Waylen, Georgina. 1994. "Women and Democratization: Conceptualizing Gender Relations in Transition Politics." World Politics 46(3): 327-354.

Waylen, Georgina. 2003. “Gender and Transitions: What do We Know?” Democratization 10(1): 157-178.

Waylen, Georgina. 2007. Engendering Transitions: Women's Mobilizations, Institutions, and Gender Outcomes. London: Oxford University Press.

Weingast, Barry. 1997. "The political foundations of democracy." American Political Science Review 91: 245-63.

Welch, Susan. 1977. "Women as Political Animals? A Test of Some Explanations for MaleFemale Political Participation Differences.” American Journal of Political Science 21(4): 711-30.

Wyndow, Paula, Jianghong Li, and Eugene Mattes. 2013. "Female Empowerment as a Core Driver of Democratic Development: A Dynamic Panel Model from 1980 to 2005.” World Development 52: 34-54.

Viterna, Jocelyn and Kathleen Fallon. 2008. "Democratization, Women's Movements, and Gender-Equitable States: A Framework for Comparison.” American Sociological Review 73: 66889.

Viterna, Jocelyn, Kathleen Fallon and Jason Beckfield. 2008. "How Development Matters: A Research Note on the Relationship between Development, Democracy, and Women's Legislative Representation.” International Journal of Comparative Sociology 49: 455-76. 


\section{Appendix}

\section{Appendix A: Theoretical background to the graphical investigation of ordinal sequences}

For two binary variables, both of which take the values as 0 and 1 , there are three ways for two variables to change from $(0,0)$ to $(1,1)$. Either Variable A can change first to $(1,0)$, both can change simultaneously to $(1,1)$, or Variable B can change first to $(0,1)$. Thus, to determine how often Variable A becomes 1 before Variable B, one simply counts the number of changes from $(0,0)$ to $(1,1)$ that go via $(1,0)$ and compare this number to the number of changes from $(0,0)$ to $(1,1)$ that are direct, or via $(0,1)$ (Figure A1a). This counting results in a frequency table similar to Table 1, but for binary characters with only four possible combinations.

For ordinal variables with multiple values the situation is more complex. Consider two comparable ordinal variables (Variable A and Variable B) varying along the same scale with the same step size - in our example all variables can take on the integer values $0,1,2,3$ and 4 . The question of interest is again if one variable tends to be larger (or smaller) than the other after a change. Partly, the general thinking is similar - if Variable A tends to be larger than Variable B then changes ending above the diagonal will be more common than changes ending below the diagonal (Figure A1b).

Partly, however, the situation is entirely different, because a multitude of other potential paths are possible. For example, one variable may become larger first at lower values while the other becomes larger first at higher values, variables may go in both directions or variables may be unrelated but one variable has a skewed distribution, a pattern that would result in more changes ending on one side of the diagonal even if no correlation exists between the two variables. Often, we may not observe processes from scratch, but in the middle of transitions, which would mean that we miss parts of the process for each country. If, for example, A tends to be larger than B in the beginning of a transition, and the opposite in the end, then we would underestimate the occurrences of $\mathrm{A}>\mathrm{B}$ if we lack more beginnings than ends of transitions. Further, and most importantly, the variables may not be comparable - how does the value 2 for freedom of speech truly compare to a value 2 of gender equality? Thus, it is important to visually inspect the movement graphs - because of this, we term the approach graphical rather than statistical.

Figure A1: Some of the potential pathways of change in (a) two binary variables and (b) two comparable categorical five state variables. 
a)

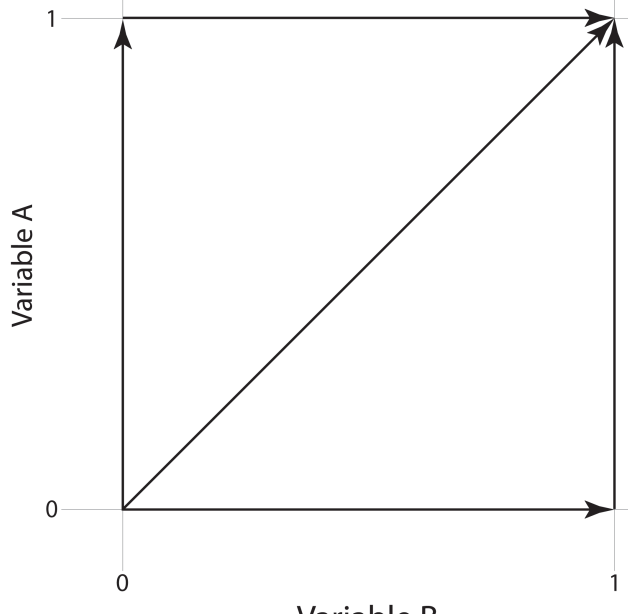

Variable B b)

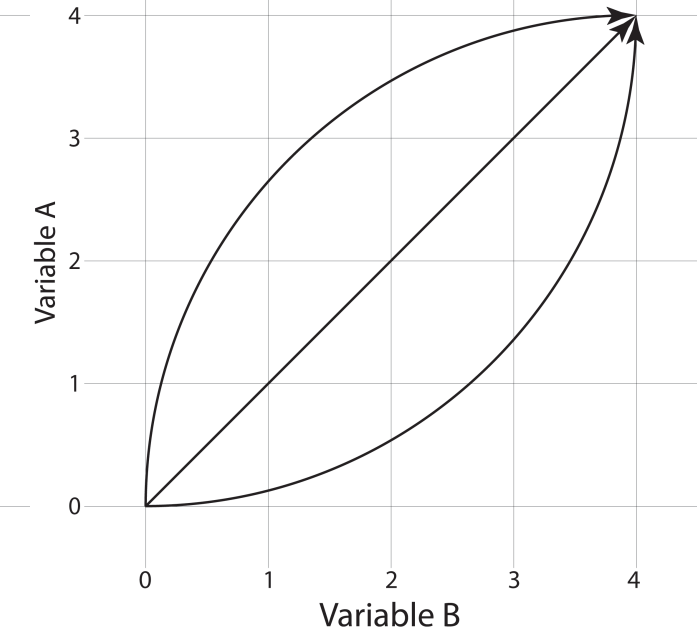




\section{Appendix B: Frequency Analysis for Subsamples}

Table B.1 to B.3 show frequency analyses for different subsamples. The results suggest the pattern that civil rights score higher values than the electoral component index prevails for the early democracies, the third wave democracies, and when the post-communist countries are excluded.

Table B.1: Relative frequency table of civil liberties and the electoral principle of democracy (1900-1945)

$$
\begin{array}{cl}
V \text { ariable } A=\underset{\text { index }}{\text { Electoral component }} & \% \text { when } B>
\end{array} \quad \text { when } B=A \text { when } B<A
$$

Variable B

Property rights for men 85

Freedom of domestic movement for men $\quad 78$

Freedom of domestic movement for women $\quad 75$

Property rights for women 75

Access to justice for men $\quad 68$

Freedom of discussion for men

$14 \quad .01$

$\begin{array}{lll}78 & 18 \\ 75 & 3.6\end{array}$

Freedom from forced labor for women

Freedom from forced labor for men $\quad 61$

Access to justice for women 58

$20 \quad 5.5$

$20 \quad 4.1$

$64-30-6.1$

Freedom of discussion for women $\quad 54 \quad 37 \quad 8.6$

Table B.2: Relative frequency table of civil liberties and the electoral principle of democracy (1974-2012)

\begin{tabular}{llll} 
Variable $A=$ Electoral component index & \% when $B>$ & \% when $B=$ & \% when $B<$ \\
Variable $B$ & $A$ & $A$ & $A$ \\
\hline Freedom of domestic movement for men & 80 & 17 & 3.3 \\
Property rights for men & 79 & 17 & 4 \\
Freedom of domestic movement for women & 78 & 17 & 4.9 \\
Property rights for women & 75 & 20 & 4.8 \\
Freedom from forced labor for women & 67 & 25 & 8.3 \\
Freedom from forced labor for men & 66 & 27 & 7.2 \\
Freedom of discussion for women & 57 & 32 & 11 \\
Freedom of discussion for men & 57 & 30 & 13 \\
Access to justice for men & 55 & 31 & 15 \\
Access to justice for women & 51 & 34 & 15
\end{tabular}


Table B.3: Relative frequency table of civil liberties and the electoral principle of democracy (postcommunist countries excluded)

$V$ ariable $A=$ Electoral component index $\quad \%$ when $B>\quad \%$ when $B=\%$ when $B<$ Variable $B$

Property rights for men

$\begin{array}{lll}A & A & A \\ 83 & 14 & 2.9 \\ 81 & 16 & 3.4 \\ 79 & 16 & 4.8 \\ 75 & 19 & 5.7 \\ 68 & 24 & 8.3 \\ 66 & 26 & 8.2 \\ 61 & 28 & 11 \\ 59 & 28 & 12 \\ 55 & 32 & 12 \\ 54 & 33 & 14\end{array}$

Freedom of domestic movement for men

Freedom of domestic movement for women

Property rights for women

Freedom from forced labor for women

Freedom from forced labor for men

Access to justice for men

Freedom of discussion for men

Freedom of discussion for women

Access to justice for women 


\section{Appendix C: Regression Analysis}

We utilize hierarchical linear regression analysis to control for the effects of potential confounding factors. The results are presented in Table A.1. The dependent variable of all the models is the electoral component index. The five civil liberty indicators for men and women are included in Model 1 to 5 as the independent variables. As the literature has suggested (Acemoglu et al. 2008, 2009), we include country fixed effects and time dummies to capture various institutional differences across countries and common trends of democratic transitions. The one-year lagged value of the dependent variable on the right-hand side is included to capture persistence in the quality of elections. Other control variables, such as the levels of economic development, income inequality, and oil production per capita, are also included ${ }^{5}$ since they have been identified as strong predictors for democratization in previous studies (see Acemoglu et al. 2009, Barro 1999, Boix and Stokes 2003). In the regression analyses, the dependent variable is one year ahead of all the independent variables.

The results suggest that except for freedom from forced labor for women, all other types of civil liberties for both men and women are significantly positively correlated to the quality of elections. Similar to the results of the Bayesian dynamical system analysis, among different types of civil liberties, with regard to property rights and freedom of discussion, women's rights seem to have greater effects than men's rights on the electoral index; while with regard to freedom of domestic movement, access to justice, and freedom from forced labor, men's rights have larger impacts. Overall, the regression analyses show that both men's and women's rights are correlated with the emergence of competitive elections. It has to be noted that even though all independent variables are lagged by one year, it is still difficult to identify the temporal relationships between the improvement of electoral quality and civil rights for both genders by regressions. Whether there is a temporal lag between the empowerment of men and women is also not clear from these models. Sequence analyses are intended to deal with these issues.

\footnotetext{
${ }^{5}$ See the V-Dem Codebook (Coppedge et al. 2014) for the data sources of these controls.
} 
Table C.1: Regression analysis on the relationship between civil liberties and the electoral principle of democracy

\section{$D V:$ Electoral component index}
(1)
(2)
(3)
(4)
(5)

$\begin{array}{llllll}\text { Civil liberty indicator } & \begin{array}{l}\text { Property } \\ \text { rights }\end{array} & \begin{array}{l}\text { Freedom of } \\ \text { domestic } \\ \text { movement }\end{array} & \begin{array}{l}\text { Access to } \\ \text { justice }\end{array} & \begin{array}{l}\text { Freedom } \\ \text { from forced discussion } \\ \text { labor }\end{array} & \begin{array}{l}\text { Freedom of } \\ \text { disculon }\end{array}\end{array}$

\begin{tabular}{|c|c|c|c|c|c|}
\hline \multirow[t]{2}{*}{ Female civil liberty } & $0.026^{* * *}$ & $0.015^{* * *}$ & $0.024 * * *$ & 0.008 & $0.040 * * *$ \\
\hline & {$[0.003]$} & {$[0.004]$} & {$[0.004]$} & {$[0.005]$} & {$[0.003]$} \\
\hline \multirow[t]{2}{*}{ Male civil liberty } & $0.016 * * *$ & $0.044 * * *$ & $0.046 * * *$ & $0.036 * * *$ & $0.026 * * *$ \\
\hline & {$[0.003]$} & {$[0.003]$} & {$[0.004]$} & {$[0.004]$} & {$[0.003]$} \\
\hline \multirow[t]{2}{*}{ (log) GDP per Capita } & $0.008^{*}$ & 0.002 & -0.000 & $0.012^{* * *}$ & 0.005 \\
\hline & {$[0.003]$} & {$[0.003]$} & {$[0.003]$} & {$[0.003]$} & {$[0.003]$} \\
\hline \multirow[t]{2}{*}{ GINI } & $-0.0004 * *$ & $-0.0007 * * *$ & $-0.0007 * * *$ & $-0.0004 * *$ & $-0.0009 * * *$ \\
\hline & {$[0.0001]$} & {$[0.0001]$} & {$[0.0001]$} & {$[0.0001]$} & {$[0.0001]$} \\
\hline \multirow[t]{2}{*}{ Urbanization } & $0.048^{*}$ & $0.039 *$ & $0.081 * * *$ & 0.029 & $0.039 *$ \\
\hline & [0.019] & {$[0.018]$} & {$[0.018]$} & [0.019] & {$[0.018]$} \\
\hline GDP growth Rate & $0.0007 * * *$ & $0.0007 * * *$ & $0.0007 * * *$ & $0.0008^{* * *}$ & $0.0007 * * *$ \\
\hline Rate & {$[0.0001]$} & {$[0.0001]$} & {$[0.0001]$} & {$[0.0001]$} & {$[0.0001]$} \\
\hline (log) Petroleum & $-0.002 * *$ & $-0.002 * *$ & $-0.002^{* *}$ & $-0.003^{* *}$ & $-0.002 *$ \\
\hline production & {$[0.0009]$} & {$[0.0009]$} & {$[0.0009]$} & {$[0.0009]$} & {$[0.0009]$} \\
\hline \multirow[t]{2}{*}{ Electoral component $t_{t-1}$} & $0.756 * * *$ & $0.699 * * *$ & $0.661 * * *$ & $0.752^{* * *}$ & $0.601 * * *$ \\
\hline & {$[0.007]$} & {$[0.008]$} & {$[0.008]$} & {$[0.007]$} & {$[0.008]$} \\
\hline \multirow[t]{2}{*}{ _cons } & -0.0214 & 0.0432 & $0.102^{* *}$ & -0.0359 & $0.0901 * *$ \\
\hline & {$[0.034]$} & {$[0.034]$} & {$[0.034]$} & {$[0.034]$} & {$[0.032]$} \\
\hline $\mathrm{N}$ & 7566 & 7566 & 7566 & 7566 & 7566 \\
\hline Countries & 128 & 128 & 128 & 128 & 128 \\
\hline adj. R-sq & 0.795 & 0.803 & 0.807 & 0.796 & 0.817 \\
\hline
\end{tabular}

- Country and year fixed effects. Standard errors in brackets. ${ }^{*} \mathrm{p}<0.05^{* *} \mathrm{p}<0.01{ }^{* * *} \mathrm{p}<0.001$. All independent variables are lagged by one year. 


\section{Appendix D: Additional Tables and Figures}

Table D.1: Relative frequencies of male and female civil liberties when change was positive

\begin{tabular}{llll}
$A=$ Males & $\%$ when $A>B$ & $\%$ when $A=B$ & \% when $A<B$ \\
$B=$ Females & & & \\
\hline Property rights & 44 & 50 & 5.7 \\
Freedom of domestic movement & 36 & 58 & 5.9 \\
Freedom from forced labor & 30 & 61 & 9.6 \\
Access to justice & 26 & 64 & 9.9 \\
Freedom of discussion & 20 & 61 & 18
\end{tabular}

Table D.2: Relative frequencies of male and female civil liberties when change was negative

\begin{tabular}{llll}
$A=$ Males & $\%$ when $A>B$ & $\%$ when $A=B$ & \% when $A<B$ \\
$B=$ Females & & & \\
\hline Property rights & 51 & 33 & 16 \\
Freedom of domestic movement & 38 & 51 & 11 \\
Access to justice & 28 & 58 & 14 \\
Freedom from forced labor & 16 & 61 & 23 \\
Freedom of discussion & 17 & 57 & 26
\end{tabular}

Table D.3: Relative frequency table of civil liberties and the electoral principle of democracy when change was positive

\begin{tabular}{llll} 
Variable $A=$ Electoral component index & \% when $B>$ & \% when $B=$ & \% when $B<$ \\
Variable $B$ & $A$ & $A$ & $A$ \\
\hline Property rights for men & 87 & 13 & 0.0 \\
Freedom of domestic movement for men & 86 & 12 & 1.6 \\
Freedom of domestic movement for women & 79 & 18 & 2.5 \\
Freedom from forced labor for men & 71 & 26 & 3.6 \\
Property rights for women & 69 & 26 & 4.8 \\
Freedom from forced labor for women & 64 & 30 & 6.6 \\
Freedom of discussion for men & 49 & 40 & 11 \\
Freedom of discussion for women & 48 & 43 & 9.3 \\
Access to justice for men & 39 & 44 & 17 \\
Access to justice for women & 31 & 50 & 20
\end{tabular}


Table D.4: Relative frequency table of civil liberties and the electoral principle of democracy when change was negative

\begin{tabular}{llll} 
Variable $A=$ Electoral component index & \% when $B>$ & $\%$ when $B=$ & \% when $B<$ \\
Variable $B$ & $A$ & $A$ & $A$ \\
\hline Property rights for men & 98 & 1.8 & 0.0 \\
Freedom of domestic movement for men & 97 & 2.5 & 0.7 \\
Freedom of domestic movement for women & 94 & 5.7 & 0.7 \\
Property rights for women & 94 & 5.4 & 0.9 \\
Freedom from forced labor for women & 92 & 6.0 & 2.0 \\
Freedom from forced labor for men & 90 & 7.6 & 2.3 \\
Access to justice for men & 76 & 19 & 5.2 \\
Access to justice for women & 74 & 20 & 5.7 \\
Freedom of discussion for women & 73 & 21 & 5.8 \\
Freedom of discussion for men & 70 & 23 & 7.0
\end{tabular}


Figure D1: Pathways of changes in civil liberty indicators and the electoral index
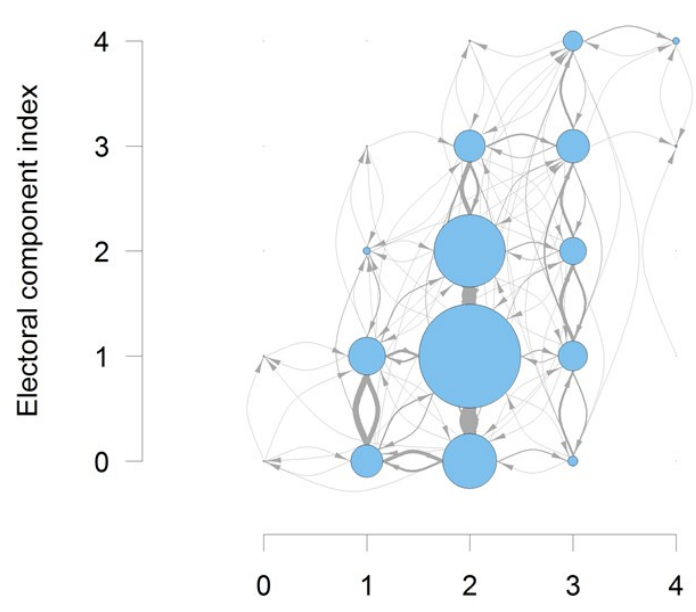

Access to justice for men
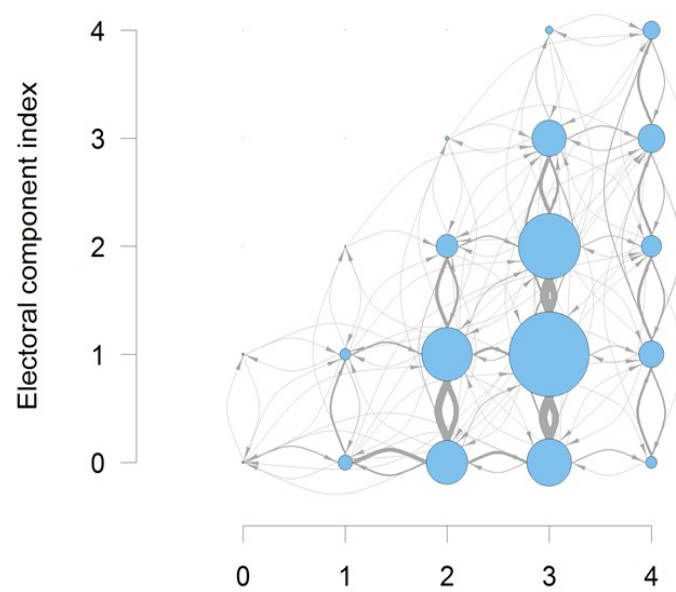

Freedom from forced labor for men

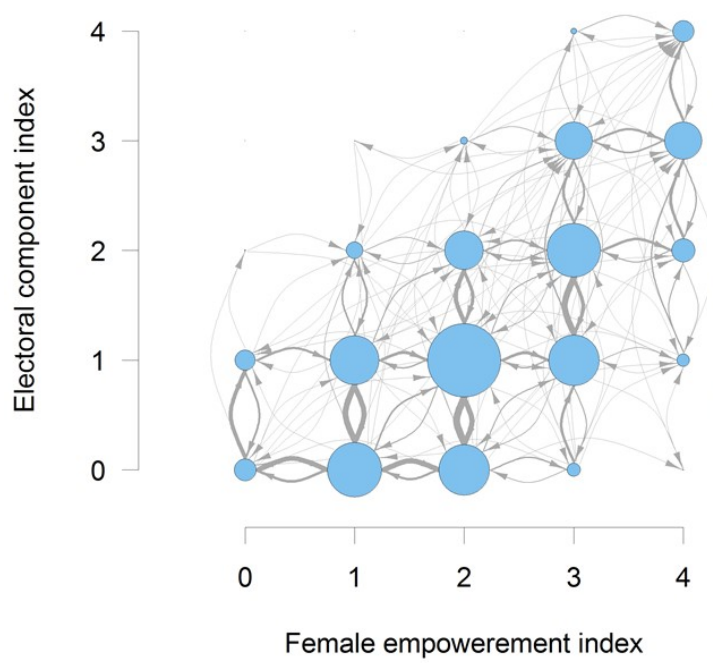

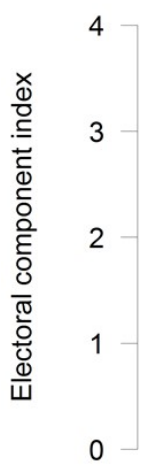

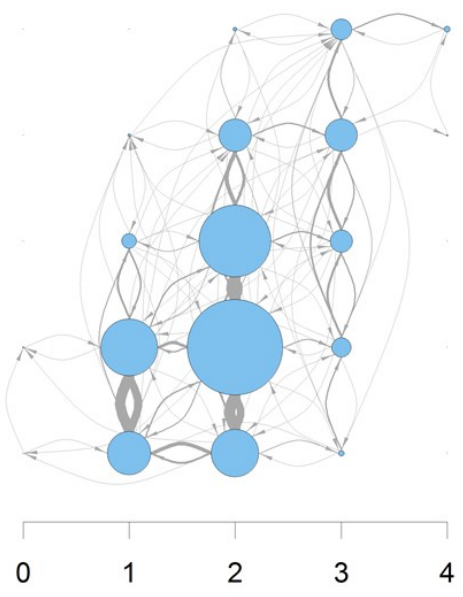

Access to justice for women
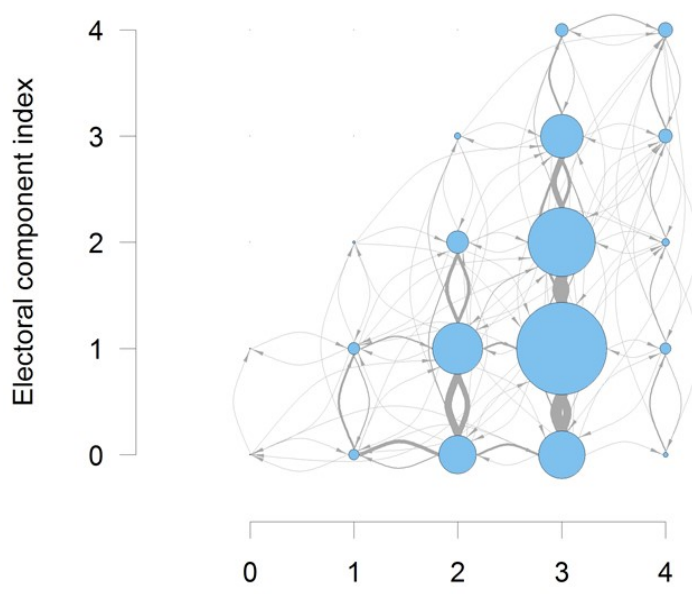

Freedom from forced labor for women
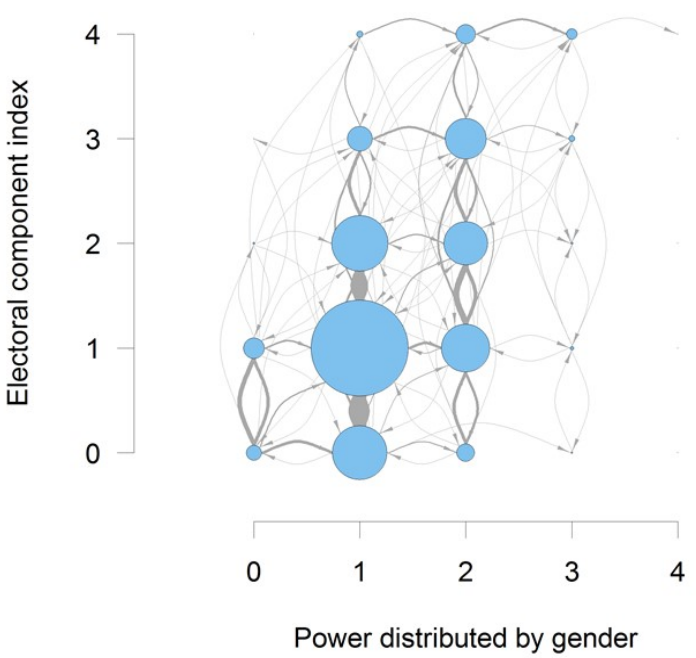

Figure D2: Comparisons between observed and expected pathways in frequency matrices of changes in civil liberty indicators and the electoral index, indicating reform paths that are more utilized than expected from the distribution of the variables alone. 

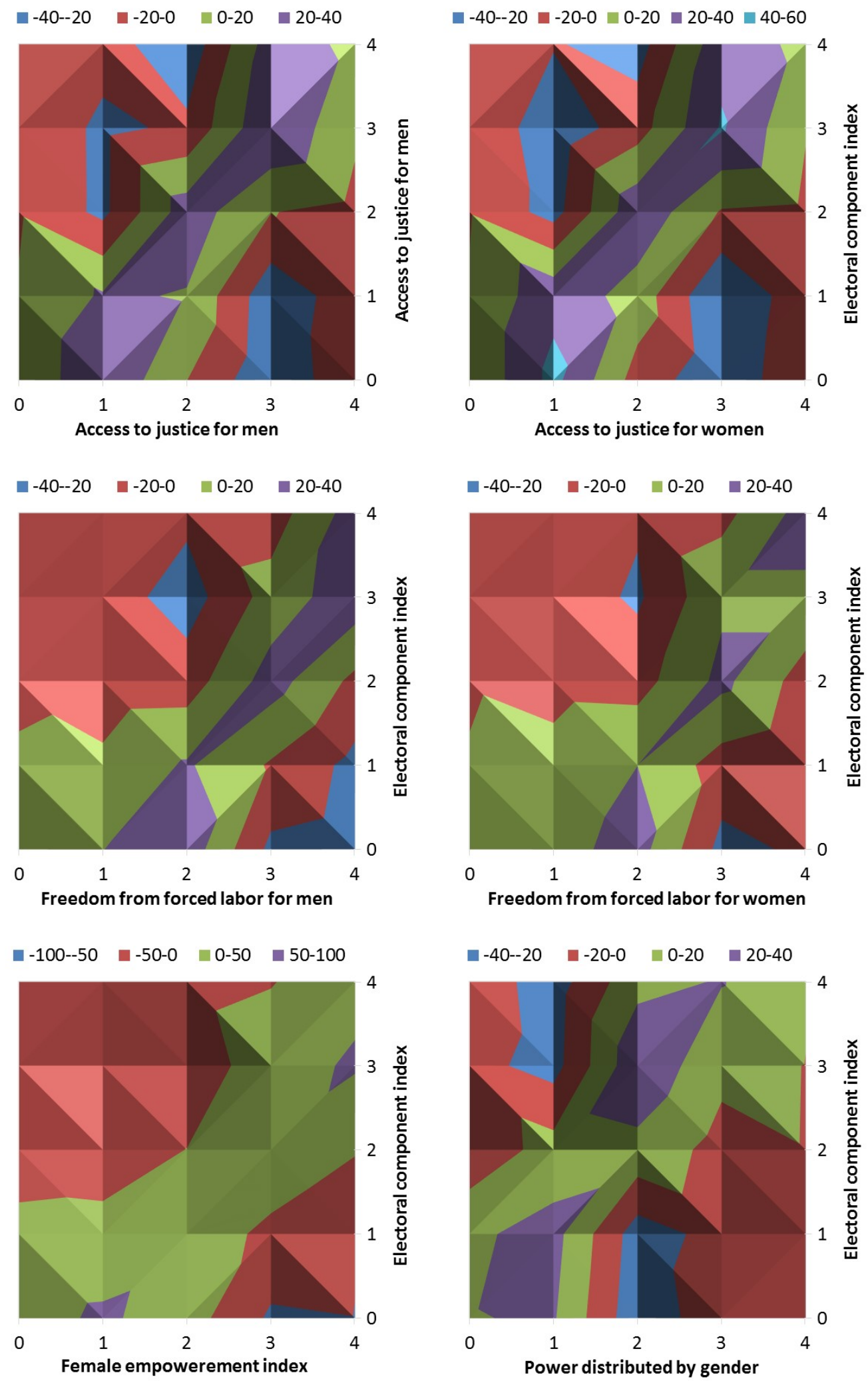